Chapman University

Chapman University Digital Commons

Business Faculty Articles and Research

Business

$11-2009$

\title{
Impact Of Mad Money Stock Recommendations: Merging Financial and Marketing Perspectives
}

\author{
Ekaterina Karniouchina \\ Chapman University \\ William L. Moore \\ University of Utah \\ Kevin J. Cooney \\ Northwest University
}

Follow this and additional works at: https://digitalcommons.chapman.edu/business_articles

Part of the Advertising and Promotion Management Commons, Broadcast and Video Studies Commons, Communication Technology and New Media Commons, Film and Media Studies Commons, Finance and Financial Management Commons, and the Marketing Commons

\section{Recommended Citation}

Karniouchina, Ekaterina V., William L. Moore, and Kevin J. Cooney. "Impact of mad money stock recommendations: merging financial and marketing perspectives." Journal of Marketing 73.6 (2009):

244-266.

DOI:10.1509/jmkg.73.6.244

This Article is brought to you for free and open access by the Business at Chapman University Digital Commons. It has been accepted for inclusion in Business Faculty Articles and Research by an authorized administrator of Chapman University Digital Commons. For more information, please contact laughtin@chapman.edu. 


\section{Impact Of Mad Money Stock Recommendations: Merging Financial and Marketing Perspectives}

\section{Comments}

This article was originally published in Journal of Marketing, volume 73, issue 6, in 2009. DOI: 10.1509/ jmkg.73.6.244

\section{Copyright}

American Marketing Association 


\section{Impact of Mad Money Stock Recommendations: Merging Financial and Marketing Perspectives}

This article relies on advertising and persuasive communications theories to uncover persistent variations in investor response to television stock recommendations targeting naive investors. The authors use an event study methodology to determine the size of the next-day abnormal market reaction to recommendations on Mad Money with Jim Cramer. Although viewers are actively looking for recommendations, the results show that any individual recommendation is still subject to many of the same communication challenges as traditional advertisements. A regression analysis finds that traditional advertising variables, such as message length, recency-primacy effects, information clutter, and source credibility, influence the size of the market reaction to a "buy" recommendation. The authors discuss implications for marketers, managers of public companies, and those interested in public policy aspects related to televised stock recommendations.

Keywords: advertising, television stock recommendations, targeted marketing, event analysis, Mad Money with Jim Cramer, marketing-finance interface

I just want to make you money, because my job is not just to entertain you, but to educate you, so call me at 1-800743-CNBC.

$$
\text { —Jim Cramer }
$$

$\mathbf{T}$ The opening line of the Mad Money with Jim Cramer television show sounds surprisingly like an advertisement. Although Jim Cramer's stock recommendations are technically not advertisements, they are persuasive messages delivered through mass media. Research in finance and economics has found evidence of a general positive reaction to "buy" recommendations aired on Mad Money taking place on the day following the broadcast of the show (e.g., Engelberg, Sasseville, and Williams 2006, 2007; Lim and Rosario 2008; Neumann and Kenny 2007). We expand these findings by using traditional advertising and persuasive communications factors to examine which

Ekaterina V. Karniouchina is Assistant Professor of Marketing, Argyros School of Business and Economics, Chapman University (e-mail: karniouc@chapman.edu). William L. Moore is David Eccles Professor of Marketing, David Eccles School of Business, University of Utah (e-mail: mktbm@ business.utah.edu). Kevin J. Cooney is a doctoral student in Marketing, Kelley School of Business, Indiana University (e-mail: kcooney@ indiana.edu). The authors acknowledge financial support from the Marketing Science Institute and Emory Marketing Institute. The authors extend thanks to the special issue editors and the three anonymous JM reviewers for their constructive comments on previous drafts of this article. In addition, they are grateful to Debbie Scammon, Jack Cooney, Jagdish Agrawal, Can Uslay, Eugenia Golubeva, Grigori Erenburg, Praveen Sinha, and participants of the Marketing Strategy Meets Wall Street conference at Emory University for their thoughtful suggestions. of these buy recommendations are likely to generate the greatest reaction. ${ }^{1}$

Although many of the shows' viewers are actively seeking recommendations, we find that traditional advertising and persuasive communications variables, such as message length, recency-primacy effects, information clutter, and source credibility, influence the size of the market reaction following a buy recommendation. In addition to uncovering potential arbitrage opportunities for investors, this research has implications for emergent targeted advertising approaches, such as various forms of advertising based on consumer Internet searches and browsing history or customized shopping portal recommendation lists, because it suggests that the communication challenges associated with traditional advertisements persist even when highly targeted messages are communicated to receptive and attentive audiences. In addition, these results should provide insights for managers who are interested in how expert third-party recommendations targeted at naive investors affect stock price, for executives who use appearances on stock recommendation shows in their public relations strategy, and for people interested in the public policy implications of providing stock recommendations to a large group of naive investors.

\footnotetext{
${ }^{1}$ We focus on buy recommendations because sell recommendations do not lend themselves to this type of analysis, partly because advertising convinces people to buy rather than sell a product and, more important, not all the viewers can act on the sell recommendations because they do not own the mentioned securities in their portfolios and/or do not use sophisticated tools, such as options or short-selling, that would allow them to trade based on the recommendation regardless of whether they own the stocks.
} 


\section{Background and Motivation for the Study}

Every day, investors are bombarded with investment recommendations in newspaper and magazine articles, on television shows, and in spam e-mails (Frieder and Zittrain 2007). Because no new information is typically embedded in these recommendations, the efficient market hypothesis would suggest that stock prices should not react to them. Nevertheless, the market reacts to such recommendations in general (e.g., Barber, Lehavy, and McNichols 2001; Elton, Gruber, and Grossman 1986; Womack 1996) and to Jim Cramer's recommendations on Mad Money in particular (e.g., Engelberg, Sasseville, and Williams 2006, 2007; Lim and Rosario 2008; Neumann and Kenny 2007).

It is believed that individual investors are highly susceptible to mass-media investment recommendations because of the high search costs associated with a wide array of available options. For example, Jain and Wu (2000) show increased resource flows to the mutual funds advertised in business periodicals. Barber and Odean (2008) find that individual investors are net buyers of stocks that have recently been mentioned in the news, are experiencing abnormal volumes, and have extreme one-day returns. Frieder and Zittrain (2007) uncover short-term market fluctuations in reaction to spam e-mails, suggesting that stock prices are affected by even the least credible forms of information.

We analyze the Mad Money show as opposed to more sophisticated financial programming because it is clearly targeted at naive investors. The Stalwart (2005), an Internet blog targeted at financial industry professionals, states that "Jim Cramer's CNBC show Mad Money is an addictive guilty pleasure... His frenzied 5-second analysis on hundreds of stocks never ceases to amuse. But we won't turn to him for investment advice ... as most of what he says simply describes the previous day's market action." This sentiment agrees with our interviews of finance professionals, including financial planners and mutual fund managers. Our interviewees stated that Mad Money's appeal is limited to those outside the financial industry. Several mutual fund managers admitted that they occasionally watch the show and even receive e-mails with Mad Money recaps, but none of them traded on the basis of the show's suggestions.

Jim Cramer specifically targets naive investors. He rarely uses complicated financial jargon or provides indepth analysis. He favors clear-cut buy/sell recommendations and does not resort to ambiguous statements that are common to this type of programming. He also incorporates a strong entertainment component in his show. Cramer resorts to a wide array of ostentatious tricks, including dressing up in costumes, shouting, using and sometimes breaking props, throwing objects on the set, and using various sound effects, all of which make his program similar to advertising environments traditionally studied by marketing scholars. Regardless of one's personal stand regarding his antics, it is difficult to dispute that Cramer succeeds in grabbing his audience's attention. The Hollywood Reporter (Gough 2006) attests that, on average, more than a quarter million viewers watch Mad Money on CNBC.
Another advantage of analyzing Mad Money is that Jim Cramer tries to minimize recommendation leaks during the taping of the show, which makes its impact more tractable. Other shows, such as Fast Money, provide more sophisticated commentaries aimed at more informed investors and often supply general insights into savvy financial products and tools (i.e., derivatives, commodities, and technical analysis) that are not suitable for an average individual investor. Moreover, the experts featured in these programs frequently appear on other network shows that provide similar recommendations during the trading day, which has a contaminating effect.

\section{Conceptual Framework}

As with any persuasive attempt, message intensity, presentation order, and source credibility can affect consumer decisions. In addition, various psychological and cognitive processes and biases may influence consumer judgment. Therefore, we use an event study methodology to quantify an individual stock's reaction to Mad Money recommendations and then use regression analysis to uncover the factors that affect the size of the resulting abnormalities. In particular, we explain the relative size of the next-day market reaction by using variables associated with traditional advertising and persuasive communication frameworks. In spirit, our investigation is similar to those in the emerging field of behavioral finance (Barberis and Thaler 2003) and marketing that demonstrate how various heuristics and biases lead to irrational stock market behaviors (Johnson, Tellis, and MacInnis 2005). We follow the framework outlined in Figure 1.

Previous research on the impact of Mad Money recommendations has documented the overall inefficiencies of financial markets. Neumann and Kenny (2007) analyze 162 buy recommendations and document an average next-day abnormal return of $1.06 \%$, which is followed by a steady price decline. Engelberg, Sasseville, and Williams (2007) analyze 391 initial buy recommendations and find that stock prices increased by an average of $2.86 \%$ on the day after the show aired but then fell back to their previous levels within several trading days. Both studies find a significant run-up in security prices before the event. Despite the host's claims regarding the show's efforts to prevent information leaks, Engelberg, Sasseville, and Williams (2007) mention information leakage as a possible explanation for this run-up. They also document that arbitrage plays by informed investors following such recommendations as short-sale volumes for recommended stocks increase on the day following recommendations and that the magnitude of the volume spike is proportional to the size of the arbitrage opportunity available.

These prior studies have also outlined factors related to underlying securities that could influence the size of the abnormal market reaction. Similarly, we include several control variables (which we discuss subsequently) that are characteristics of the underlying securities (rather than the recommendations) that could be related to the behavior of naive and informed investors. Such factors are captured by the far outer level of Figure 1. For example, we include the 


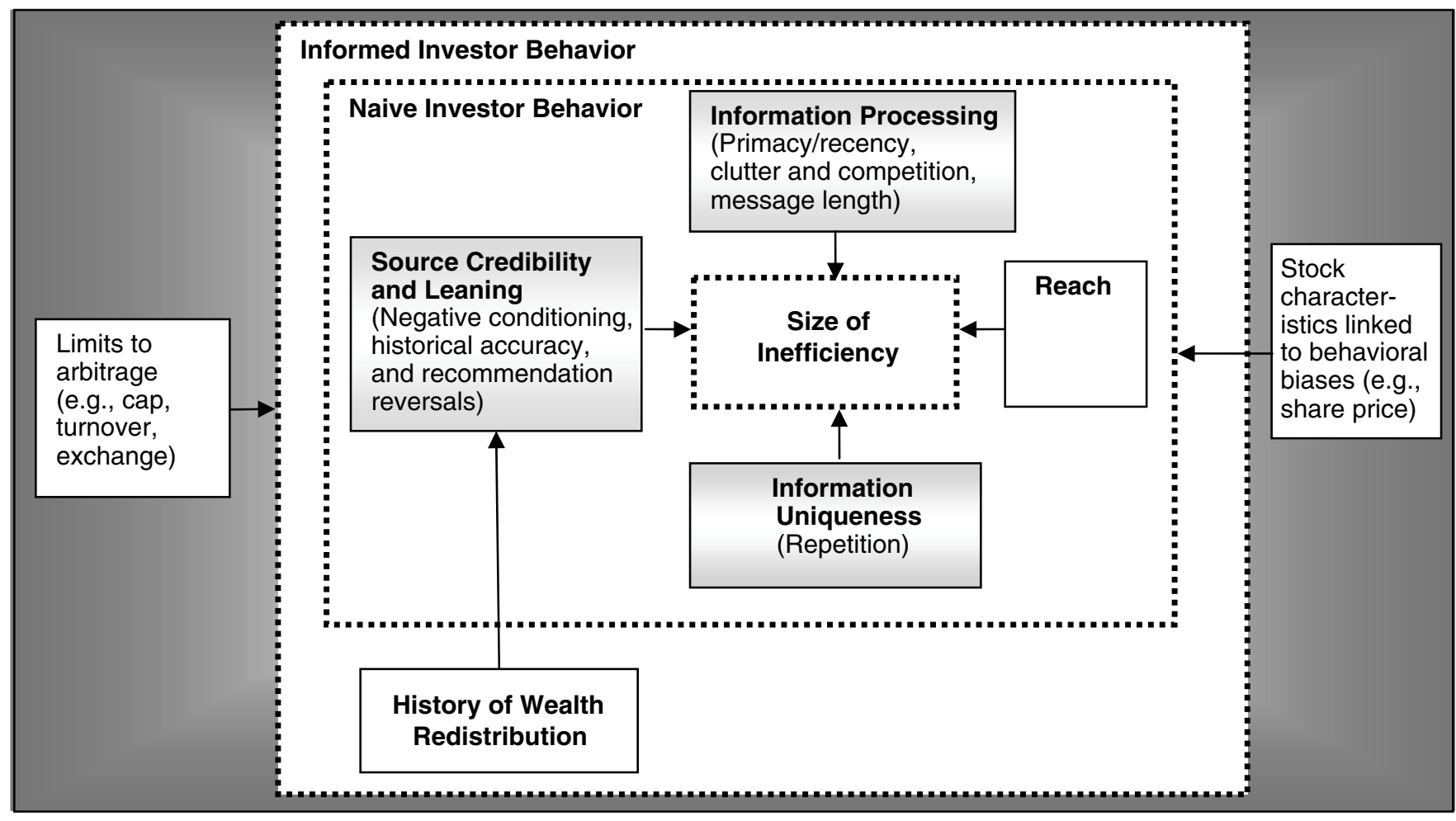

market capitalization of the underlying security because, in general, larger cap stocks are more liquid and have fewer limits to arbitrage (i.e., factors diminishing the ability of informed traders to trade away market inefficiencies). It is more difficult for informed market players to sell small cap stocks short because this requires them to borrow shares that may not be available.

In addition to accounting for the security-related aspects, limits to arbitrage, and history of wealth redistribution, the inner box of Figure 1, which is linked to naive investor behavior, examines the impact of show-related characteristics by introducing traditional advertising and persuasive communications variables to explain which recommendations receive the strongest reaction from naive investors. These variables are linked to information uniqueness, information-processing environment, reach, and aspects of source credibility; we discuss these in greater detail in the next section.

\section{Research Questions and Hypotheses}

\section{Information Uniqueness}

We consider the impact of information uniqueness by examining new versus repeat recommendations. Advertising effectiveness has been found to be susceptible to "threshold" effects (Blair 1987; Pechmann and Stewart 1988) and "wearout" effects (Haley 1978; Simon 1982;
Winter 1973), leading to an inverted U-shaped relationship between the number of exposures and advertising effectiveness (for a summary of this research stream, see Anand and Sternthal 1990). Jim Cramer's recommendations to buy certain stocks are similar to traditional television advertisements in that both are impersonal broadcast messages persuading investors/consumers to make a particular purchase. At the same time, there are some critical differences. For example, stock recommendations operate in a highinvolvement environment. Viewers are actually looking for recommendations rather than enduring an advertisement to watch a show. ${ }^{2}$ If viewers are actively looking for unique stock recommendations, we would not expect any threshold effect, just a rapid wearout effect. For example, Busse and Green (2002) show that investors incorporate television stock recommendations from CNBC's Opening Call and Midday Call almost instantly. In addition, investors could have acted on previous recommendations, and already hav-

\footnotetext{
${ }^{2}$ Another difference is that Cramer is not a paid endorser. In addition, traditionally, a message must have an identifiable sponsor to be considered an advertisement (e.g., American Marketing Association 1960). However, this demarcation is growing less relevant today as companies attempt to fly under the radar of skeptical consumers by devising advertisements that are less identifiable and, at times, completely covert (e.g., Dahlén and Edenius 2007).
} 
ing a stock in their portfolio could deter them from acting on the recommendation again. ${ }^{3}$

$\mathrm{H}_{1}$ : Market reaction to an initial stock recommendation is stronger than it is to subsequent recommendations.

\section{Information Processing}

We hypothesize that several factors related to the information-processing environment of the Mad Money show are related to abnormal returns. These include the presence of primacy and recency effects, clutter and competition from concurrent recommendations, and message length. We discuss each in turn.

Primacy-recency effects. Pieters and Bijmolt (1997) find that there are modest recall advantages associated with first (last) commercials in a block of television commercials, indicating the presence of primacy (recency) effects. Webb and Ray (1979) find that $70 \%$ of people in their sample exhibited recall patterns that were consistent with a primacy effect. We hypothesize that similar effects increase the size of abnormal returns following individual recommendations because it is more likely that individual investors will act on recommendations that are more readily retrievable from memory.

$\mathrm{H}_{2}$ : The primacy effect of stock pick order is associated with a stronger market response.

$\mathrm{H}_{3}$ : The recency effect of stock pick order is associated with a stronger market response.

Clutter and competition. Stocks in the same industry/ market segment may compete for an individual investor's attention because of industry knowledge or expectations regarding sector performance. The presence of competing stock picks in general (regardless of sector membership) is likely to reduce the chances of an individual stock being purchased by the viewers. Here, we draw the connection with the work of Burke and Srull (1988), who show that the presence of competitive advertising affects consumer memory.

Advertising clutter can create consumer overload, decrease viewer attention span, and interfere with cognitive responses (Keller 1987, 1991; Webb 1979; Zhao 1997). Marketing literature finds that, in general, recall for commercials/brands decreases as clutter increases (Webb 1979; Webb and Ray 1979). Webb and Ray (1979) find that in unaided recall situations, people can recall only a certain number of advertised brands, regardless of how many commercials they view. Kent and Allen (1993) show that competitive clutter substantially reduces brand name recall scores. Although there is convincing evidence that clutter interferes with advertising effectiveness, its effects may not transfer to television stock recommendations. Webb (1979)

\footnotetext{
${ }^{3}$ To control for portfolio effects associated with previous recommendations for the repeat stocks, we introduce the coverage intensity variable that captures the number of times the stock has been recommended by Cramer divided by the number of days since his first recommendation.
}

finds that the detriment from clutter is present only in lowinvolvement situations (for a detailed summary of clutterrelated advertising studies, see Brown and Rothschild 1993). Engelberg, Sasseville, and Williams (2007) examine the effect of the number of non-Lightning Round (we discuss these Mad Money segment designations in greater detail in the "Data" section) recommendations on the nextday price abnormality and find a negative but nonsignificant relationship.

$\mathrm{H}_{4}$ : An increase in the number of total recommendations in the same show decreases the response to a recommendation.

$\mathrm{H}_{5}$ : An increase in the number of similar (i.e., same industry) recommendations in the same show decreases the response to a recommendation.

Message length. As late as 1965, most U.S. television commercials were 60 seconds in length. By the 1980s, $94.6 \%$ were 30 -second commercials. Now, the mix is approximately 38\% 15-second commercials and 54\% 30second commercials (Television Bureau of Advertising 2009). This finding indicates that many advertising professionals did not believe that the extra length was worth the cost, and it is consistent with research conducted at the time 30-second commercials were introduced (e.g., Wheatley 1968), which found only directionally, but not significantly, stronger results in terms of brand recall, attitude change, or product desire for 60-second versus 30-second commercials. In contrast, Anand and Sternthal (1990) find support for the general notion that the time available for message processing influences the effectiveness of the message, and Pieters and Bijmolt (1997) find that both duration of the commercial and competition from other commercials in the same block influence recall.

Previous research on the response to Mad Money recommendations has found some evidence of a relationship between message length and size of response. Engelberg, Sasseville, and Williams (2007) find a 2\% lower $(p<.01)$ response to recommendations in the highly condensed Lightning Round segment than in the non-Lightning Round segments. Lim and Rosario (2008) compare the responses to the caller-initiated versus host-initiated picks and find that the abnormal returns are more pronounced for more elaborate host-initiated recommendations. However, in both studies, message length is confounded with whether the recommendation was viewer- or host-initiated because the Lightning Round and Sudden Death segments contain primarily less elaborate and viewer-initiated picks. Still, in the context of Mad Money, there are three reasons to expect that the more elaborate recommendations should be associated with stronger investor reaction. First, the message is longer, giving more time for information processing. Second, there are typically fewer stocks in this program segment and, therefore, less clutter. Third, these are stocks that Cramer has thought about in more detail. We provide a more nuanced examination of this issue by identifying more detailed and lengthy recommendations that are classified as Special Mention, regardless of the segment they appear in, and by modeling the response for each segment of the program. 
$\mathrm{H}_{6}$ : Market response to more (less) elaborate recommendations is stronger (weaker).

\section{Reach}

Even with a lot of on- and offline word-of-mouth activity surrounding Cramer's recommendations, it is reasonable to assume that the more people who watch the show, the greater is the impact of his message, and the larger is the size of the naive investor pool exposed to his recommendations. Therefore, we hypothesize that greater reach is associated with greater stock price reaction. Previous literature (Engelberg, Sasseville, and Williams 2007) has found only directional, but not statistically significant, support for this hypothesis.

$\mathrm{H}_{7}$ : The size of the television audience is positively associated with market response.

\section{Source Credibility and Leaning}

Finally, we examine the aspects related to source credibility (Hovland, Janis, and Kelley 1953) and learning. In particular, we examine the classic dimensions of perceived source credibility: expertise and trustworthiness. Expertise in this setting could be defined as the host's track record on a particular security, and overall trustworthiness could be inferred from the consistency of the host's position on a particular stock as well as the overall historical performance. We also take on a learning perspective and argue that investors not only pay attention to various credibility considerations but also learn in response to persistent wealth redistribution from naive to informed investors.

Negative conditioning. If price movements are exploited by institutional players and if individual investors learn that price shifts following Cramer's recommendations are temporary and thus lose their trust in the host, the negative conditioning will make these investors less likely to follow future recommendations. As first suggested by Engelberg, Sasseville, and Williams (2006, 2007), we hypothesize that the large price jumps that follow the earlier broadcasts subside over time because of the influence of informed arbitrage players and gradual naive investor learning evoked by such strategies.

Moreover, when investors are led to believe that stock prices will increase, but they actually decrease after purchase, the situation is akin to the impact of deceptive or false advertising, which has been studied by marketing scholars. In the marketing literature (i.e., Olson and Dover 1978 , p. 30), deception is "considered to occur when consumers acquire demonstrably false beliefs as a function of exposure to an advertisement." In a longitudinal experiment, Olson and Dover (1978) demonstrate that false claims and subsequent product trial result in significant reduction in pretrial purchase intentions.

$\mathrm{H}_{8}$ : The magnitude of stock price fluctuations induced by the show declines over time.

Historical accuracy. Although Cramer is not explicitly trying to sell anything, his brand and credibility are depen- dent on the correctness of his picks because they are tied to his perceived expertise. If investors are engaged in learning (Erdem and Keane 1996), we expect them to update their assessment of Cramer's expertise on particular stocks. This would make them more likely to react positively to a particular stock recommendation when his previous recommendations have been successful.

$\mathrm{H}_{9}$ : Accuracy of the host's previous pick for a given stock influences the strength of market response.

Recommendation reversals. We also examine the impact of recommendation reversal and its interaction with the accuracy of previous predictions, which has not been considered in previous studies. Recommendation reversals are often confusing for naive investors, and they also affect the trustworthiness of the host. In marketing literature, attribution theory is often used to explain consumer reaction to various unexpected occurrences; this theory suggests that the perceived reason for an event influences consumer motivation and subsequent behavior (Bettman 1979). This framework has helped shed light on various marketing issues; for example, several studies successfully use this approach to predict consumer reactions to product failure (e.g., Folkes 1984). McGill (1991) points out that consumers' attribution for product failure varies with causal background. If a stock-picking service is viewed as a product, an inaccurate pick would be similar to a product failure. Therefore, the background information must be considered-for example, whether a previous recommendation on the stock was correct and whether a reversal is an admittance of a mistake or just an acknowledgment of a changing environment. When future price movements contradict one of the host's previous recommendations, a subsequent recommendation reversal could lead either to strong investor reaction or to the loss of credibility on the part of the host.

Recommendation reversals share similarities with a political candidate's policy changes. Political science literature finds that, among other things, policy changes increase voter uncertainty (Alvarez and Nagler 2002). Tavits (2007) differentiates between different political domains and argues that policy reversals could be rewarded (punished) by voters when the underlying issue is pragmatic (ideological). Policy reversals on pragmatic issues are perceived as signs of flexibility and adaptation to changing economic conditions, whereas reversals that strike a voter's ideological cord are perceived as signs of inconsistency, thus undermining candidates' credibility and voter rapport. If viewers take a pragmatic perspective, they could regard reversals as necessary adaptations to changing conditions. These reversals will be taken seriously by investors if they infer that new information was sufficiently persuasive to cause Cramer to reverse his previous recommendation. Alternatively, if viewers do not take a pragmatic stance, recommendation reversals could undermine the host's credibility and make investors doubt his expertise when it comes to a particular security (which could later turn into distrust of the show in general).

$\mathrm{H}_{10}$ : When the host reverses his recommendation on a stock, the resulting stock price change is greater than the one 
that would have taken place on a repeated recommendation.

$\mathrm{H}_{11}$ : Accuracy of previous prediction moderates market response to recommendation reversals.

\section{Control Variables}

The general level of awareness of a stock may influence the level of postrecommendation response regardless of the number of previous exposures. Finance literature points out that familiarity fuels investment (Huberman 2001); therefore, investors may have more confidence in buying stock in a company that they are already familiar with when Cramer recommends it. Similarly, marketing literature points out that advertising for familiar brands attracts the largest amount of attention to the advertised brand, which improves subsequent brand memory (Pieters, Warlop, and Wedel 2002).

However, it is more likely that if the stock is well known, investors will perceive fewer opportunities to beat the market. If "noise traders" search for "unique" information, they would be more likely to respond to recommendations of relatively unknown stocks. It is also possible that recommendations for unknown stocks would be more effective because of the lack of preconceived notions about them. Such findings would echo those of Winter (1973), who finds that advertising can produce significant attitude change only in people initially unfamiliar with the brand.

"Popular" stocks have the highest following by analysts and the highest percentage ownership by institutional investors and market makers. ${ }^{4}$ These informed investors are the most likely candidates to exploit the market inefficiencies created by individual investors. These more liquid and widely traded stocks also have low limits to arbitrage. Therefore, we expect these stocks to be less susceptible to recommendations. At the same time, "speculative" stocks (e.g., stocks with higher turnover) are more susceptible to recommendations because of the low institutional ownership and higher overall volatility. Therefore, we control for preevent market capitalization and turnover rates. We also control for possible day-of-the-week effects and/or memory decay by creating a set of weekday dummy variables and a variable that captures the number of days between the recommendation and market opening.

Security prices could influence the size of inefficiencies produced by the show. Investors may view "cheaper" stocks as bargains. Even after controlling for market cap, which would capture the potentially higher limits to arbitrage and reduced liquidity associated with "cheaper" stocks, we expect these stocks to be associated with higher inefficiencies. In addition, we control for whether Jim Cramer owns the security in question (as a part of his charitable trust) because this factor may raise some trust issues on the part of investors. Finally, because trading mechanisms, volatility, and spreads differ across exchanges, we view the exchange on which a given security is traded as a factor in determining the size of market abnormality.

${ }^{4}$ In this study, we use market capitalization as a measure of stock popularity.

\section{Data}

\section{Mad Money Data}

We obtained the recommendations data from a subscription-based Mad Money recap provider (i.e., an independent Web site that captures the recommendations appearing on Mad Money). This site supplies detailed daily recaps of the show. This data source has several advantages: (1) It operates independently from Mad Money; (2) it recaps the recommendations in the order in which they appear on the program (many other recap providers disseminate segment information in alphabetical order); and (3) the provider creates special designations for some stocks, which eliminates the need for the use of researcher judgment in classifying the recommendations (e.g., a "Special Mention" designation indicates that Jim Cramer discussed the stock in detail).

We analyze recommendations across different segments of the show. The Executive Interview segment is the most detailed segment. With rare exceptions (which we exclude from our data set because these instances do not translate into buy recommendations), chief executive officers (CEOs) provide an upbeat view of the market and a positive company outlook. Cramer opens and wraps the show with fairly detailed discussions of select stocks. Therefore, we discuss the recommendations that appear in the Opening (also referred to as "First") and Closing segments of the show in greater detail. The Main segment is the segment during which the stocks receive an average amount of attention; our regression analysis treats these stocks as the base category. In both the Lightning Round and the Sudden Death segments, the host provides a fast-paced series of stock picks (many of them are in response to viewers' calls regarding a recommendation on a specific security, and Cramer quickly responds with his opinion). The difference between the two segments is that the Lightning Round takes place in the beginning of the show and Sudden Death appears at the end. We exclude the "Am I Diversified?" segment of the program because the recommendations provided in this segment are specific to the caller portfolio.

We also include special designations by the recap provider in the analysis because they represent the average depth of recommendations associated with these groupings. Some stocks are designated as "Mon Back" stocks (Jim Cramer's term for "C'mon back"), suggesting that Cramer would back up the truck and load it up with stock. Some stocks receive a "Special Mention" designation, indicating that the stock received special attention from Cramer in terms of time spent discussing it and the strength of his opinion. These stocks are not the same as "Special Discussion" stocks that Engelberg, Sasseville, and Williams (2007) mention. They use this term to describe nonLightning Round stocks. In our sample, Special Mention is the designation given by the third party. These are the stocks the recap provider recognizes as having received special attention/endorsement from the host (they appear across all segments of the show, including Lightning Round and Sudden Death; however, they are underrepresented in these segments). In addition, we capture a special designa- 
tion for the stocks that are part of Jim Cramer's charitable trust portfolio.

This study uses 8269 unambiguous buy recommendations for stocks trading on NASDAQ, AMEX, or NYSE that aired between November 1, 2005, and July 31, 2007. We used sell recommendations that aired during the same period to estimate the variables pertaining to coverage intensity, accuracy of previous recommendations, and recommendation reversals for buy recommendations. Of the initial 8269 buy recommendations, we carried out our regressions analysis on the 8160 observations that had enough data for the estimation period, as specified in the "Event Study" section.

\section{Television Ratings Data}

We purchased daily television ratings data for the Mad Money show from Nielsen Media Research. The data cover the same period as our stock picks database.

\section{Financial Data}

We obtained all financial data from the Center for Research in Security Prices (CRSP). We carried out the event studyrelated portion of the analysis using Eventus software. We accessed both financial data and Eventus software through Wharton Research Data Services.

\section{Event Study}

Event studies have become a popular tool in several fields beyond finance (Balasubramanian, Mathur, and Thakur 2005; Kalaignanam, Shankar, and Varadarajan 2007). They have been used to enhance the understanding of various marketing domains, such as brand equity (Simon and Sullivan 1993), product placement (Wiles and Danielova 2009), product innovation (e.g., Chan, Lakonishok, and Sougiannis 2001; Chaney, Devinney, and Winer 1991; Eliashberg and Robertson 1988; Sharma and Lacey 2004; Sood and Tellis 2009), celebrity endorsements (Agarwal and Kamakura 1995), and customer service (Balasubramanian, Mathur, and Thakur 2005).

This approach uses the returns of the market portfolio as a benchmark for normal returns and then detects any deviations from it. We assume that the event (or recommendation) takes place at $\mathrm{t}=0$ (see Figure 2). We use a 100-day estimation window (between days -145 and -46) to estimate the normal or expected return and use the $(-10,20)$ event window when we analyze the pattern of abnormal

FIGURE 2

\section{Event Study Timeline}

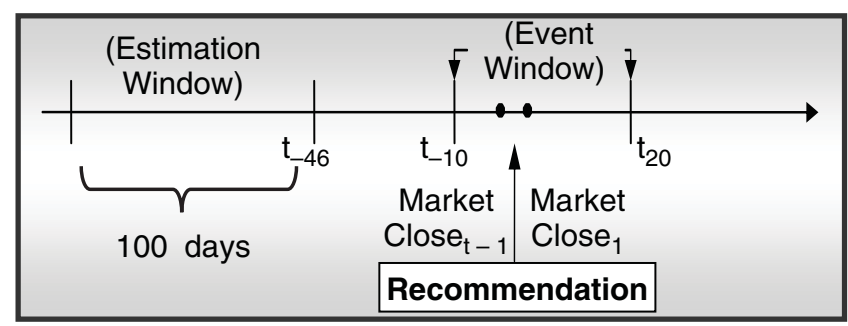

returns associated with recommendations. We use this broader event window to provide a direct comparison with the only published study on Mad Money recommendations by Neumann and Kenny (2007), who use the same event window while demonstrating the overall pattern of abnormal returns. Because Cramer makes his recommendations after the close of the market at 6:00 P.M., we are particularly interested in the next-day abnormal return, or the $(1,1)$ event window. This approach is consistent with previous research that points out that the impact of recommendations is incorporated into prices within the first few trades during the next trading session, and the best way to measure the impact of media recommendations is to consider the $(1,1)$ event window (e.g., Neumann and Kenny 2007; Pari 1987).

Following Campbell, Lo, and MacKinlay (1997), we define the abnormal return as the actual ex post return of the security over the event window less the normal return of the firm over the event window. The normal return is the expected return if the event (recommendation) did not take place. For each firm i and event date $\tau$,

$$
\mathrm{AR}_{\mathrm{it}}^{*}=\mathrm{R}_{\mathrm{it}}-\mathrm{E}\left[\mathrm{R}_{\mathrm{it}} \mid X_{\mathrm{t}}\right] \text {, }
$$

where $\mathrm{AR}_{\mathrm{it}}^{*}, \mathrm{R}_{\mathrm{it}}$, and $\mathrm{E}\left[\mathrm{R}_{\mathrm{it}}\right]$ are the abnormal, actual, and normal returns, respectively, and $\mathrm{X}_{t}$ is the conditioning information to determine normal performance. We begin with the most common variation of the normal return model, known as the "market model" (for a detailed description of applications within the marketing domain, see Srinivasan and Bharadwaj 2004):

$$
\mathrm{R}_{\mathrm{it}}=\alpha_{\mathrm{i}}+\beta_{\mathrm{i}} \mathrm{R}_{\mathrm{mt}}+\varepsilon_{\mathrm{it}}
$$

where

$$
\begin{aligned}
\mathrm{R}_{\mathrm{it}}= & \text { the return of stock } \mathrm{i} \text { at time } \mathrm{t} \\
\mathrm{R}_{\mathrm{mt}}= & \text { the monthly return on the CRSP equally } \\
& \text { weighted index, } \\
\beta_{\mathrm{i}}= & \text { a measure of stock i's sensitivity to market } \\
& \text { changes, and } \\
\varepsilon_{\mathrm{it}}= & \text { the error term. }
\end{aligned}
$$

However, it has been recommended to find a model that best fits the market to make the event study more efficient (Srinivasan and Bharadwaj 2004). Fama and French (1996) propose a multifactor model that explains several assetpricing anomalies that exist in the market:

$$
\mathrm{R}_{\mathrm{it}}=\alpha_{\mathrm{i}}+\beta_{\mathrm{i}} \mathrm{R}_{\mathrm{mt}}+\mathrm{s}_{\mathrm{i}} \mathrm{SMB}_{\mathrm{t}}+\mathrm{h}_{\mathrm{i}} \mathrm{HML}_{\mathrm{t}}+\varepsilon_{\mathrm{it}},
$$

where the two additional factors are related to market anomalies with respect to stocks of different market capitalization and value versus growth stocks:

$$
\begin{aligned}
\mathrm{SMB}_{\mathrm{t}}= & \text { the difference between average returns of } \\
& \text { small and large cap portfolios, and } \\
\mathrm{HML}_{\mathrm{t}}= & \text { the difference between average returns on high } \\
& \text { versus low B/M portfolios. } 5
\end{aligned}
$$

The Fama-French three-factor model captures the majority of market inefficiencies, but it fails to capture momentum (Carhart 1997). Therefore, we incorporate Carhart's (1997)

5Portfolios are formed on the basis of book-to-market ratios. 
momentum factor. The resulting equation is known as the four-factor model:

(4)

$$
\mathrm{R}_{\mathrm{it}}=\alpha_{\mathrm{i}}+\beta_{\mathrm{i}} \mathrm{R}_{\mathrm{mt}}+\mathrm{s}_{\mathrm{i}} \mathrm{SMB}_{\mathrm{t}}+\mathrm{h}_{\mathrm{i}} \mathrm{HML}_{\mathrm{t}}+\mathrm{u}_{\mathrm{i}} \mathrm{UMD}_{\mathrm{t}}+\varepsilon_{\mathrm{it}},
$$

where $\mathrm{UMD}_{\mathrm{t}}$ is the average return on high-performing portfolios less the average return on low-return portfolios. Using the four-factor model, we define abnormal returns as follows:

(5) $\mathrm{AR}_{\mathrm{it}}=\mathrm{R}_{\mathrm{it}}-\left(\hat{\alpha}_{\mathrm{i}}+\hat{\beta}_{\mathrm{i}} \mathrm{R}_{\mathrm{mt}}+\hat{\mathrm{s}}_{\mathrm{i}} \mathrm{SMB}_{\mathrm{t}}+\hat{\mathrm{h}}_{\mathrm{i}} \mathrm{HML}_{\mathrm{t}}+\hat{\mathrm{u}}_{\mathrm{i}} \mathrm{UMD}_{\mathrm{t}}\right)$,

where $\hat{\alpha}_{i}, \hat{\beta}_{i}, \hat{s}_{i}, \hat{h}_{i}$, and $\hat{u}_{i}$ are generalized autoregressive conditional heteroskedasticity $(\mathrm{GARCH})(1,1)$ estimates of $\alpha_{i}, \beta_{i}, s_{i}, h_{i}$, and $u_{i}$.

We use a GARCH $(1,1)$ model (as suggested by Bollerslev 1986) because it allows the conditional variance to change as a function of the past-realized residuals and past variances. Boehmer, Musumeci, and Poulsen (1991) and Corhay and Tourani-Rad (1996) present evidence that this method provides more efficient estimators of regression parameters and leads to more robust conclusions than the traditional event study methodology.

In addition to estimating abnormal returns using Equation 5 over the $(-0,20)$ window, we examine the preshow price buildup in the $(-10,0)$ window and the day following the show $(1,1)$, and we evaluate the postreaction price drift by studying the postevent window $(2,20)$. We also conduct a volume-based event study, in which daily volume data are centered on a single date for each firm (for details, see Campbell and Wasley 1996). Volume event studies are similar to the market model event studies described in Equation 2, except that we use log-transformed volume data (i.e., logtransformed percentages of shares outstanding) in place of the returns.

\section{Tests}

\section{Statistical Tests of Abnormal Returns}

We use several tests to identify the significance of resulting inefficiencies. We use a traditional time-series standard deviation t-test (Brown and Warner 1985) to detect the significance of the abnormal returns over a specified time frame. We use various other tests to ensure that our results are not driven by event-induced volatility. We use a standardized cross-sectional test that is better suited for detecting return abnormalities than the conventional standard deviation test in the presence of autocorrelation, event clustering, and event-induced heteroskedasticity. In these settings, it is more powerful than the Brown-Warner test while being equally well specified (Boehmer, Musumeci, and Poulsen 1991). The generalized sign test uses a normal approximation to the binomial distribution and determines whether the differences in the number of positive and negative returns are significant at the desired confidence level (for details, see Cowan 1992; Sprent 1989).

\section{Accessing the Impact of Volatility Changes}

In addition to using tests that are robust to event-induced volatility changes, we use a supplemental model that explicitly incorporates such volatility changes across different event windows. Following Mathur and colleagues (2002), we estimate a multivariate regression model (MRM) based on Zellner's (1962) seemingly unrelated regression method. The following model explicitly recognizes the possible shifts in volatility coefficients:

(6) $r_{t}=\hat{a}+\hat{a}^{\prime} D_{s}+\hat{b} r_{m k t}+\hat{b}^{\prime} D_{0}+\hat{b}^{\prime \prime} D_{s} r_{m k t}+\sum_{i=1}^{3} \hat{C}_{i} D_{i}+e_{t}$,

where

$r_{t}=$ the rate of return of the portfolio of firm returns for day $\mathrm{t}$;

$r_{m k t}=$ the rate of return on the market index;

$\hat{a}=$ regression constant up to the announcement date;

$\hat{a}^{\prime}=$ shift in regression constant in the postevent period;

$\hat{b}=$ systematic risk coefficient during the event period;

$\hat{b}^{\prime}=$ shift in systematic risk coefficient during the $(-10,20)$ event period;

$\hat{b}^{\prime \prime}=$ shift in systematic risk coefficient during the postevent period;

$\mathrm{D}_{0}=$ shift information dummy variable equal to 1 if during the $(-10,20)$ period;

$\mathrm{D}_{\mathrm{s}}=$ shift information dummy variable equal to 1 if during the postevent period;

$\mathrm{D}_{\mathrm{i}}=$ shift information dummy variable for each event window: $(-10,0),(1,1)$, and $(2,20)$; and

$\hat{\mathrm{C}}_{\mathrm{i}}=$ abnormal return coefficient for each event window: $(-10,0),(1,1)$, and $(2,20)$.

Again following Mathur and colleagues (2002), we use White's (1982) procedure to correct for heteroskedasticity in residuals. If identified abnormal returns are not influenced by event-induced volatility, the returns for different event windows would be consistent across the stable beta model and the MRM in which beta is allowed to shift across volatility regimes.

\section{Results of Event Study}

\section{Overall Patten of Abnormal Returns}

We replicated previous research by examining the abnormal price fluctuations associated with all the buy recommendations that appear on the show. Consistent with previous research (e.g., Engelberg, Sasseville, and Williams 2006, 2007; Lim and Rosario 2008), we find that stocks recommended during the show experienced abnormal returns before the recommendation (see Figure 3). We find a significant abnormal return of $.50 \%$ on the day following buy recommendations (see Table 1); however, starting with Day 2 , there is a significant drop in security prices because the unwarranted sharp price increase triggers a profit-taking sell-off by informed investors. It takes the stocks between six and seven trading sessions to return to their prerecommendation values. Although Jim Cramer himself warns viewers against immediately acting on his recommendations and suggests that investors do their own due diligence (Cramer 2006), the data show that investors immediately "jump" on his recommendations and lose money (at least in 
FIGURE 3

Cumulative Abnormal Returns (CARs) Following Mad Money Buy Recommendations

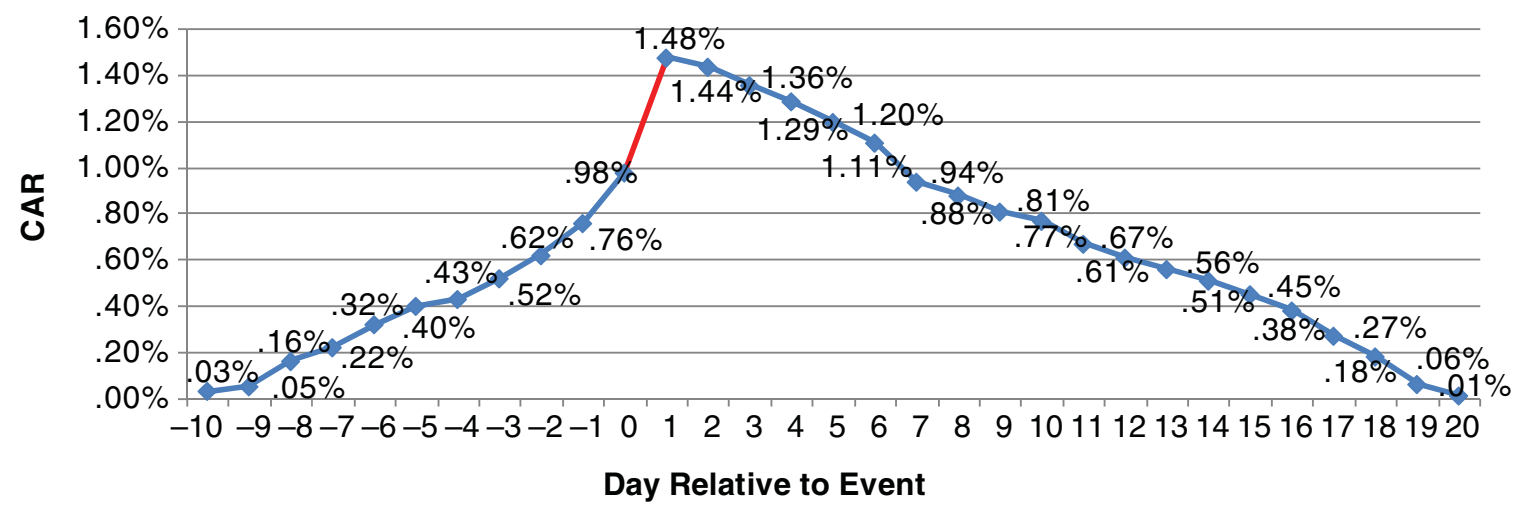

TABLE 1

Mean Cumulative Abnormal Return (CAR) for Buy Recommendations (Fama-French Momentum TimeSeries Model, Equally Weighted Index, GARCH [1, 1] Error Structure)

\begin{tabular}{|c|c|c|c|c|c|c|}
\hline Days & $\mathbf{N}$ & CAR & $\begin{array}{l}\text { Positive: } \\
\text { Negative }\end{array}$ & $\begin{array}{l}\text { Portfolio Time- } \\
\text { Series (CDA) t }\end{array}$ & $\begin{array}{c}\text { Cross-Sectional } \\
t\end{array}$ & $\begin{array}{c}\text { Generalized } \\
\text { Sign z }\end{array}$ \\
\hline $\begin{array}{l}(-10,0) \\
(1,1) \\
(2,20)\end{array}$ & $\begin{array}{l}8160 \\
8160 \\
8159\end{array}$ & $\begin{array}{r}.96 \% \\
.50 \% \\
-1.49 \%\end{array}$ & $\begin{array}{l}4394: 3766^{*} \\
4425: 3735^{*} \\
3551: 4608^{*}\end{array}$ & $\begin{array}{r}12.936^{\star} \\
22.316^{\star} \\
-15.335^{\star}\end{array}$ & $\begin{array}{r}9.269^{*} \\
16.587^{*} \\
-13.720^{*}\end{array}$ & $\begin{array}{l}10.997^{\star} \\
11.685^{\star} \\
-7.675^{\star}\end{array}$ \\
\hline
\end{tabular}

${ }^{*} p<.001$.

Notes: CDA = crude dependence adjustment.

the short run) as a result. Prices continue to fall far below the prerecommendation levels to their pre-run-up values. This indicates that the preshow run-up may not be driven by fundamentals either and that Cramer's endorsement (which possibly brings more scrutiny to the stocks) drives stock prices down closer to their intrinsic values (for daily abnormal return information, see Table 2).

A legitimate question to ask is why the informed investors do not immediately correct these large showinduced inefficiencies. It is possible that institutional investors pay attention to momentum considerations and therefore are initially reluctant to short-sell the stocks that have been climbing for a period of time. There are also numerous constraints on the actions of the short-sellers: Diamond and Verrecchia (1987) and Senchack and Starks (1993) address the effect of short-selling constraints on price reactions. Short-sales constraints include direct monetary costs of borrowing shares, the difficulty of establishing a short position (e.g., insufficient pool of shares to borrow), forced covering of short positions, potential short squeeze, and so forth. These and other factors interfere with immediate price adjustments and prevent informed investors from completely trading away inefficiencies induced by the show. It may also be questioned why uninformed investors allow the preevent run-up. We suspect that the run-up could be caused by information leakage regarding a future recommendation (as suggested by Engelberg, Sasseville, and Williams 2006), or it could be attributable to contaminating events taking place within the event window; we explore this latter possibility subsequently.

\section{Robustness Checks}

We performed robustness checks on the equally weighted four-factor model used in this study by varying model specifications. Alterations in model specification (market, three-, and four-factor), estimation method (ordinary least squares or GARCH [1, 1]), and weighting scheme (value versus equal weighting index) did not have a material influence on the findings. Neither did the length of the estimation period (255 days versus 100 days).

Furthermore, we estimated the MRM described in Equation 6. In particular, we investigated whether the abnormal returns are driven by changes in volatility. The results of the MRM model presented in Table 3 show that abnormal returns are not influenced by changes in the systematic risk.

Neither the event nor the postevent beta shift coefficients are significant, indicating that there is no change in underlying volatility. Moreover, we get the same estimate for the abnormal return for the $(1,1)$ period compared with the models with a stable beta, $.5 \%$, on the day following the recommendation. This model also detects the significant run-up during the $(-10,0)$ period and a significant decline during the $(2,20)$ period. We also find a negative shift in the intercept after the event, indicating that the negative trend of 
TABLE 2

Summary of Market Reaction to Buy Recommendations

\begin{tabular}{|c|c|c|c|c|c|c|c|}
\hline Day & $\mathbf{N}$ & MAR & CAR & $\begin{array}{l}\text { Portfolio Time- } \\
\text { Series (CDA) t }\end{array}$ & $\begin{array}{c}\text { Standardized } \\
\text { Cross- } \\
\text { Sectional (z) }\end{array}$ & $\begin{array}{c}\text { Generalized } \\
\text { Sign (z) }\end{array}$ & $\begin{array}{c}\text { MAV } \\
\text { (Significance } \\
\text { of } z \text { ) }\end{array}$ \\
\hline-10 & 8160 & $.03 \%$ & $.03 \%$ & $1.394 \dagger$ & 1.251 & $1.623^{\dagger}$ & $22.13 \%$ *** \\
\hline-9 & 8160 & $.02 \%$ & $.05 \%$ & .782 & .747 & .204 & $20.69 \%$ *** \\
\hline-8 & 8160 & $.11 \%$ & $.16 \%$ & $4.725^{\star \star \star}$ & $2.497^{\star \star}$ & $1.889^{\star}$ & $24.53 \%$ *** \\
\hline-7 & 8160 & $.06 \%$ & $.22 \%$ & $2.532^{\star *}$ & $2.383^{\star \star *}$ & -.04 & $24.35 \%$ *** \\
\hline-6 & 8160 & $.10 \%$ & $.32 \%$ & $4.521^{\star \star \star}$ & $3.621^{\star \star \star}$ & $2.310^{\star}$ & $27.39 \%$ *** \\
\hline-5 & 8160 & $.08 \%$ & $.40 \%$ & $3.591^{\star \star \star}$ & $3.261^{\star \star \star}$ & $2.465^{\star \star}$ & $27.46 \%$ *** \\
\hline-4 & 8160 & $.03 \%$ & $.43 \%$ & 1.193 & 1.033 & -.328 & $27.13 \%$ *** \\
\hline-3 & 8160 & $.09 \%$ & $.52 \%$ & $3.899^{* * *}$ & $3.305^{\star \star \star}$ & $2.842^{\star \star}$ & $31.82 \%$ *** \\
\hline-2 & 8160 & $.10 \%$ & $.62 \%$ & $4.389^{\star * *}$ & $3.988^{\star \star *}$ & $2.509^{\star \star}$ & $34.04 \%$ *** \\
\hline-1 & 8160 & $.14 \%$ & $.76 \%$ & $6.220^{\star * \star}$ & $5.069^{\star \star \star}$ & $3.085^{\star \star}$ & $38.36 \%$ *** \\
\hline 0 & 8160 & $.22 \%$ & $.98 \%$ & $9.660^{\star * *}$ & $7.043^{\star \star \star}$ & $5.036^{\star \star \star}$ & $55.12 \%$ *** \\
\hline 1 & 8160 & $.50 \%$ & $1.48 \%$ & $22.316^{\star * *}$ & $16.587^{\star \star \star *}$ & $11.685^{\star \star *}$ & $73.13 \%$ *** \\
\hline 2 & 8159 & $-.04 \%$ & $1.44 \%$ & $-1.801^{*}$ & $-1.734^{\star}$ & -.893 & $43.34 \%$ *** \\
\hline 3 & 8158 & $-.08 \%$ & $1.36 \%$ & $-3.596^{\star * *}$ & $-3.420^{\star \star \star *}$ & $-2.989^{\star \star}$ & $36.90 \%$ *** \\
\hline 4 & 8158 & $-.07 \%$ & $1.29 \%$ & $-3.267^{* * *}$ & $-3.288^{\star \star \star *}$ & $-1.592 \dagger$ & $34.32 \%$ *** \\
\hline 5 & 8159 & $-.09 \%$ & $1.20 \%$ & $-4.095^{\star \star \star}$ & $-3.730^{\star \star \star}$ & $-2.755^{\star \star}$ & $31.11 \%$ *** \\
\hline 6 & 8159 & $-.09 \%$ & $1.11 \%$ & $-4.071^{* * *}$ & $-4.175^{\star \star \star}$ & $-4.307^{\star \star \star}$ & $27.55 \%$ *** \\
\hline 7 & 8159 & $-.17 \%$ & $.94 \%$ & $-7.510^{* * *}$ & $-7.367^{\star \star \star *}$ & $-4.839^{\star \star \star}$ & $26.57 \%$ *** \\
\hline 8 & 8158 & $-.06 \%$ & $.88 \%$ & $-2.883^{\star *}$ & $-2.893^{\star *}$ & $-1.393 \dagger$ & $22.31 \%^{\star \star *}$ \\
\hline 9 & 8158 & $-.07 \%$ & $.81 \%$ & $-3.167^{\star \star *}$ & $-3.038^{\star \star}$ & $-3.853^{\star \star \star}$ & $24.57 \%^{\star \star *}$ \\
\hline 10 & 8158 & $-.04 \%$ & $.77 \%$ & $-1.931^{*}$ & $-1.844^{\star}$ & $-1.526 \dagger$ & $24.31 \%$ *** \\
\hline 11 & 8157 & $-.10 \%$ & $.67 \%$ & $-4.583^{\star \star \star}$ & $-4.561^{\star \star \star}$ & $-2.579^{\star \star}$ & $21.44 \%$ *** \\
\hline 12 & 8157 & $-.06 \%$ & $.61 \%$ & $-2.814^{\star \star}$ & $-2.663^{\star \star}$ & -1.094 & $23.47 \%$ *** \\
\hline 13 & 8158 & $-.05 \%$ & $.56 \%$ & $-2.391^{* *}$ & $-2.355^{\star \star}$ & $-1.659^{*}$ & $24.31 \%$ *** \\
\hline 14 & 8158 & $-.05 \%$ & $.51 \%$ & $-2.227^{\star}$ & $-2.143^{\star}$ & $-1.437 \dagger$ & $27.38 \%$ *** \\
\hline 15 & 8157 & $-.06 \%$ & $.45 \%$ & $-2.628^{\star \star}$ & $-2.474^{\star \star}$ & $-1.293^{\dagger}$ & $22.63 \%$ *** \\
\hline 16 & 8157 & $-.07 \%$ & $.38 \%$ & $-3.355^{\star \star \star}$ & $-3.374^{\star \star \star}$ & $-2.912^{* *}$ & $20.70 \%$ *** \\
\hline 17 & 8157 & $-.11 \%$ & $.27 \%$ & $-4.924^{\star \star \star}$ & $-4.776^{\star \star \star}$ & $-4.796^{\star \star \star}$ & $22.94 \%$ *** \\
\hline 18 & 8157 & $-.09 \%$ & $.18 \%$ & $-4.030^{\star \star \star}$ & $-3.780^{\star \star \star}$ & $-1.870^{\star}$ & $23.27 \%$ *** \\
\hline 19 & 8156 & $-.12 \%$ & $.06 \%$ & $-5.553^{\star * *}$ & $-5.229^{\star \star \star}$ & $-4.276^{\star \star \star}$ & $23.58 \%$ *** \\
\hline 20 & 8155 & $-.05 \%$ & $.01 \%$ & $-2.027^{\star}$ & $-1.873^{\star}$ & -.984 & 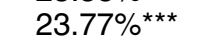 \\
\hline
\end{tabular}

$\dagger p<.10$.

${ }^{\star} p<.05$.

${ }^{\star *} p<.01$

${ }^{\star * *} p<.001$.

Notes: $\mathrm{MAR}=$ mean abnormal return, $\mathrm{CAR}=$ cumulative abnormal returns, $\mathrm{CDA}=$ crude dependence adjustment, and $\mathrm{MAV}=$ mean abnormal volume.

TABLE 3

Results of the MRM Model

\begin{tabular}{|c|c|c|c|c|c|c|c|c|}
\hline & \multicolumn{2}{|c|}{ Constant } & \multicolumn{3}{|c|}{ Beta } & \multicolumn{3}{|c|}{$\begin{array}{c}\text { Coefficients of the Information } \\
\text { Dummies }\end{array}$} \\
\hline & Overall & Post & Overall & Event & Post & $D(1,1)$ & $D(-10,0)$ & D $(2,20)$ \\
\hline $\begin{array}{l}\text { Estimates } \\
\text { T-statistic }\end{array}$ & $\begin{array}{l}.0008 \\
29.57^{\star}\end{array}$ & $\begin{array}{l}-.001 \\
-29.58^{*}\end{array}$ & $\begin{array}{c}1.32 \\
36.95^{\star}\end{array}$ & $\begin{array}{l}-.054 \\
-1.47\end{array}$ & $\begin{array}{l}-.045 \\
-1.24\end{array}$ & $\begin{array}{l}.0050 \\
16.39^{\star}\end{array}$ & $\begin{array}{l}.0007 \\
7.74^{\star}\end{array}$ & $\begin{array}{c}-.001 \\
-18.17^{*}\end{array}$ \\
\hline
\end{tabular}

${ }^{*} p<.001$.

postrecommendation price adjustment persists beyond the specified event window. This long-term price adjustment could be related to the notion that viewers are calling about high-sentiment stocks that are traditionally associated with lower expected returns (Frazzini and Lamont 2008), and the show simply triggers the value-adjustment mechanism associated with these widely favored, overvalued securities. We examined the long-term returns for these securities and found a significant downward adjustment of $-4.74 \%$ during the six months following the recommendation.

\section{Contaminated Events}

We conducted an additional analysis to ensure that the market reaction to Jim Cramer's recommendations is not an artifact of his or his viewers' stock selection metrics (e.g., Cramer tends to recommend stocks just before the earnings 
announcements). To control for all the contaminating factors, we isolated a subsample of "clean" observations. We opted for this approach rather than splitting the entire data set into clean and contaminated subsamples because of the time-consuming nature of identifying contaminated events. We randomly selected 250 observations. We defined a contaminating event as any announcement of restructuring, merger and acquisition activity, dividends, earnings announcements, new product releases, new debt or equity issuance, executive team changes, or other material changes in company operations (e.g., announcement of a new government contract or the clearance of a regulatory stage by a drug). A detailed analysis of press releases and Securities and Exchange Commission regulatory filings identified 63 (of 250) uncontaminated observations.

An event analysis for this clean subsample of observations finds that there is no significant price run-up in the $(-10,0)$ event window. The results of the contamination study indicate that much of the preevent run-up is attributable to the selection criteria tied to contaminating events. However, we are not able to conclude definitively that there is no leakage before stock recommendation, because it is possible that the leakages are strategically made around recommendations that involve contaminating events. Further investigation is needed to completely rule out the leakage possibility.

The abnormal market reaction for the $(1,1)$ event window in the clean subsample is $.90 \%(\mathrm{t}=3.5, p<.01)$. This larger abnormal reaction could have occurred because (1) the impact of a recommendation is more easily identifiable in lieu of other contaminating events and (2) the clean subsample contains a larger proportion of small cap stocks because, in general, large corporations had more contaminating events.

After the announcement, stocks begin to gravitate to their preannouncement levels. It takes them seven trading sessions to come back to their original price levels. Overall, with the exception of the absence of the preevent run-up, the clean sample results are consistent with our findings for the overall sample. Not only does the market react to Mad Money recommendations, but this reaction is also at least as large or even larger in absence of contaminating events.

\section{Volume Event Study Results}

Table 2 presents a summary of the event-related daily transaction volume reaction. We find an abnormal increase in trading volume on the trading day following the buy recommendations. Recommended stocks are already experiencing abnormal activity before the show, but the show further stimulates trading activity. Note that for every day in the event window $(-10,20)$, the mean abnormal volume is positive and significant $(p<.0001)$. The day after the show airs, stocks experience a significant $(p<.0001)$ abnormal trading volume increase of $73.13 \%$ (Figure 4 depicts daily abnormal trading volume).

\section{Buy Recommendations Across Different Segments}

Table 4 summarizes the event study results across different show segments and special designations. The Main, Opening, and Closing segments are associated with abnormal returns of $1.07 \%, 1.23 \%$, and $.54 \%$, respectively, on the day following the show. The Main and Opening segments have a greater impact than the Closing segment, which indicates a possible presence of primacy effects or the viewers not watching until the end of the program. Stocks in these more elaborate segments are associated with significantly higher next-day abnormal returns than stocks in the less elaborate Lightning Round (.20\%) and Sudden Death (.15\%) segments.

Surprisingly, the stocks featured in the CEO Interview segment experience abnormal returns of approximately $.74 \%$ on the day of the show, which is followed by an $.99 \%$ abnormal return on the day following the show, indicating

FIGURE 4

Mean Abnormal Volume (MAV) for Buy Recommendations

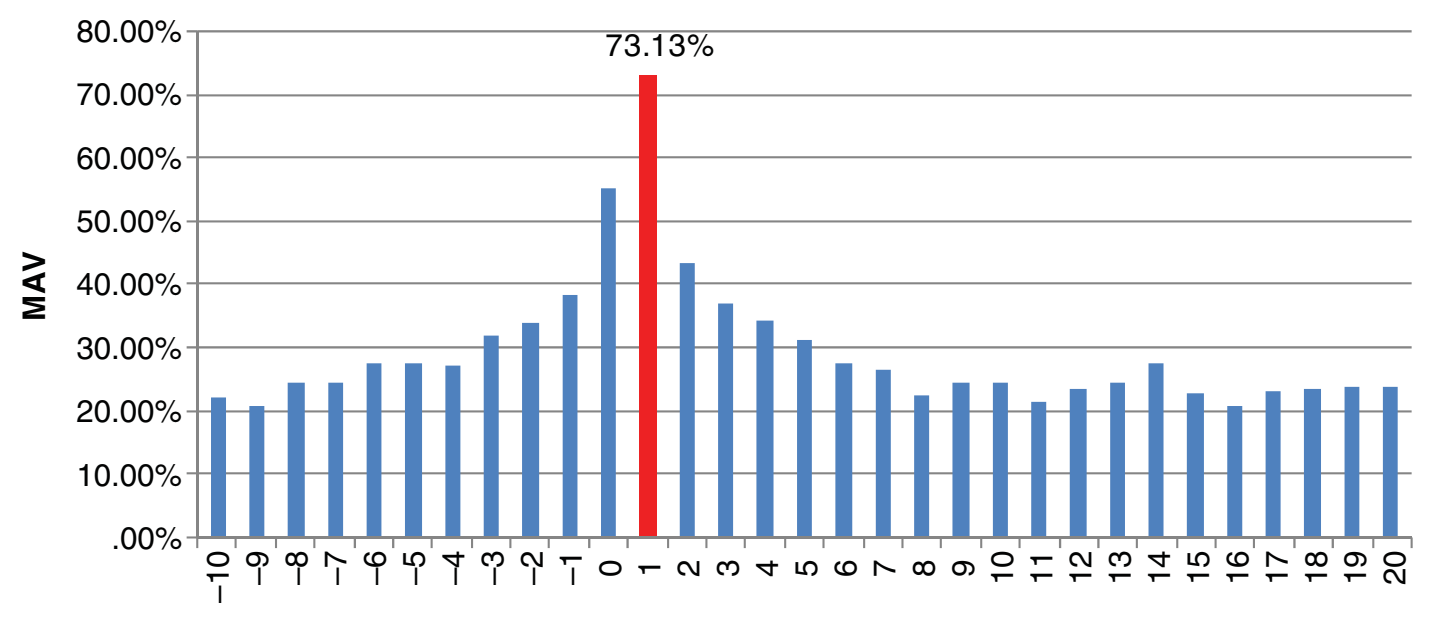

Day Relative to Event 
TABLE 4

Mean Cumulative Abnormal Return (CAR) Across Different Segments and Designations

\begin{tabular}{|c|c|c|c|c|c|c|c|}
\hline Group & Days & $\mathbf{N}$ & CAR & $\begin{array}{l}\text { Positive: } \\
\text { Negative }\end{array}$ & $\begin{array}{l}\text { Portfolio Time- } \\
\text { Series (CDA) t }\end{array}$ & $\begin{array}{c}\text { Cross- } \\
\text { Sectional t }\end{array}$ & $\begin{array}{c}\text { Generalized } \\
\text { Sign z }\end{array}$ \\
\hline Opening & $(-10,0)$ & 704 & $1.58 \%$ & $411: 293^{\star \star \star}$ & $6.574^{\star \star \star}$ & $4.360^{* \star *}$ & $5.534^{\star \star *}$ \\
\hline \multirow[t]{2}{*}{ Segment } & $(+1,+1)$ & 704 & $1.23 \%$ & $463: 241^{\star \star \star}$ & $17.085^{\star \star \star}$ & $10.635^{\star \star \star}$ & $9.456^{\star \star \star}$ \\
\hline & $(+2,+20)$ & 704 & $-1.32 \%$ & $305: 399^{\star \star}$ & $-4.199^{\star \star \star}$ & $-3.945^{\star \star \star}$ & $-2.463^{\star \star}$ \\
\hline \multirow[t]{3}{*}{ Main Segment } & $(-10,0)$ & 1663 & $1.89 \%$ & $1003: 660^{\star \star *}$ & $10.663^{\star \star \star}$ & $9.234^{\star \star *}$ & $10.108^{\star * *}$ \\
\hline & $(+1,+1)$ & 1663 & $1.07 \%$ & $962: 701^{\star \star \star}$ & $20.007^{\star \star \star}$ & $11.484^{\star \star \star}$ & $8.095^{\star \star \star}$ \\
\hline & $(+2,+20)$ & 1662 & $-1.12 \%$ & $747: 915^{\star \star}$ & $-4.803^{\star \star \star}$ & $-4.739^{\star \star \star}$ & $-2.435^{\star \star}$ \\
\hline Closing & $(-10,0)$ & 689 & $.99 \%$ & $359: 330^{\star}$ & $3.376^{\star \star \star}$ & $3.559^{\star \star *}$ & $2.194^{*}$ \\
\hline \multirow{2}{*}{ Segment } & $(+1,+1)$ & 689 & $.54 \%$ & $400: 289^{\star \star \star}$ & $6.113^{\star \star \star}$ & $5.988^{\star \star \star}$ & $5.321^{\star \star \star}$ \\
\hline & $(+2,+20)$ & 689 & $-.81 \%$ & $306: 383^{*}$ & $-2.112^{\star}$ & $-2.181^{\star}$ & $-1.848^{\star}$ \\
\hline \multirow[t]{3}{*}{ CEO Interview } & $(-10,0)$ & 132 & $2.11 \%$ & $75: 57^{\star}$ & $3.849^{\star \star \star}$ & $2.881^{\star \star}$ & $1.994^{\star}$ \\
\hline & $(+1,+1)$ & 132 & $.99 \%$ & $87: 45^{\star \star \star}$ & $5.984^{\star \star \star}$ & $4.752^{\star \star \star}$ & $4.085^{\star \star \star}$ \\
\hline & $(+2,+20)$ & 132 & $-1.66 \%$ & $56: 76 \dagger$ & $-2.308^{\star}$ & $-1.968^{\star}$ & $-1.315^{\dagger}$ \\
\hline Lightning & $(-10,0)$ & 4807 & $.58 \%$ & $2480: 2327^{\star \star *}$ & $6.270^{\star \star \star}$ & $4.040^{\star \star \star}$ & $5.450^{\star * \star}$ \\
\hline \multirow[t]{2}{*}{ Round } & $(+1,+1)$ & 4807 & $.20 \%$ & $2455: 2352^{\star \star *}$ & $7.251^{\star \star \star}$ & $6.529^{\star \star \star}$ & $4.728^{\star \star *}$ \\
\hline & $(+2,+20)$ & 4807 & $-1.75 \%$ & $2067: 2740^{\star \star *}$ & $-14.411^{\star \star \star}$ & $-12.109^{\star \star \star}$ & $-6.477^{\star \star *}$ \\
\hline \multirow[t]{3}{*}{ Sudden Death } & $(-10,0)$ & 261 & $-.20 \%$ & $116: 145$ & -.503 & -.493 & -1.039 \\
\hline & $(+1,+1)$ & 261 & $.15 \%$ & $125: 136$ & 1.187 & .912 & .077 \\
\hline & $(+2,+20)$ & 261 & $-1.14 \%$ & $112: 149 \dagger$ & $-2.144^{\star}$ & $-1.986^{\star}$ & $-1.534 \dagger$ \\
\hline Special & $(-10,0)$ & 2547 & $1.56 \%$ & $1462: 1085^{\star \star \star}$ & $10.305^{\star \star \star}$ & $9.137^{\star \star *}$ & $9.636^{\star \star \star}$ \\
\hline \multirow[t]{2}{*}{ Mention } & $(+1,+1)$ & 2547 & $1.27 \%$ & $1632: 915^{\star \star \star}$ & $27.828^{\star \star \star}$ & $18.277^{\star \star \star}$ & $16.379^{\star \star \star}$ \\
\hline & $(+2,+20)$ & 2547 & $-1.33 \%$ & $1127: 1420^{\star \star \star}$ & $-6.678^{\star \star \star}$ & $-6.844^{\star \star \star}$ & $-3.652^{\star * \star}$ \\
\hline \multirow[t]{3}{*}{ 'Mon Back } & $(-10,0)$ & 215 & $-1.68 \%$ & 92:123† & $-3.021^{\star \star}$ & $-3.019^{\star \star}$ & $-1.364 \dagger$ \\
\hline & $(+1,+1)$ & 215 & $.87 \%$ & $139: 76^{\star \star *}$ & $5.190^{\star \star \star}$ & $5.319^{\star \star \star}$ & $5.056^{\star \star \star}$ \\
\hline & $(+2,+20)$ & 215 & $-2.17 \%$ & $86: 129^{\star}$ & $-2.962^{\star \star}$ & $-3.734^{\star \star *}$ & $-2.183^{\star}$ \\
\hline
\end{tabular}

$+p<.10$

${ }^{*} p<.05$.

${ }^{\star *} p<.01$.

${ }^{* \star *} p<.001$

Notes: CDA = crude dependence adjustment.

either that Cramer contacts the CEOs of companies on the move or that show appearances require advanced scheduling and information about the CEO's visit gets leaked.

As we expected, stocks that the recap provider has classified as Special Mention get the biggest boost the day after the show airs (1.27\%). 'Mon Back stocks also receive a relatively large boost (.87\%); however, investors are a bit cautious despite the host's strong endorsement because these are often stocks that Cramer suggests have bottomed out (indicating that some investors are too conservative to use a "catching the falling knife" strategy).

\section{Initial Versus Repeat Recommendations $\left(\mathrm{H}_{\mathbf{1}}\right)$}

We could not obtain a sample of initial recommendations only, because the show started airing in March 2005 and our sample starts in November 2005. However, we separated our sample into the first observation for a particular security versus repeat recommendations for the same security. The first subsample contains all first-time recommendations that aired during the observed period (we refer to this subsample as "initial" recommendations). The results of the analysis across the two subsamples appear in Table 5. Consistent with $\mathrm{H}_{1}$, the next-day stock market increase for the initial recommendations is $1.42 \%$, which is significantly higher than the $.36 \%$ average for the repeat recommendations. ${ }^{6}$ Overall, our results provide strong support for $\mathrm{H}_{1}$.

6Mean comparison is significant at a $99.9 \%$ level.
Furthermore, the $1.42 \%$ estimate is conservative because some of the recommendations in our initial recommendation sample are repeat recommendations (Engelberg, Sasseville, and Williams's [2007] estimate for initial recommendations was twice as large). Preshow price buildup is more pronounced for initial-recommendation stocks (price increases are probably the reason the stocks catch the viewers' and host's attention). In the $(-10,0)$ event window, initial (repeat) recommendations gain $2.02 \%$ (.80\%). In addition to the next-day price increase and preshow buildup differences, it takes initial-recommendation stocks much longer (approximately 17 trading sessions) to bounce back to the preshow levels (it takes repeat-recommendation stocks only 5 to 6 sessions). Because of these differences and factors related to historical accuracy and recommendations reversals (which are applicable to repeat recommendations only), we analyze the impact of message factors on these two types of recommendations separately.

\section{Regression Analysis}

We test $\mathrm{H}_{2}-\mathrm{H}_{11}$ by estimating two regression equations, one for the initial- and one for the repeat-recommendations sample. Because our goal is to determine the factors that drive the size of abnormalities, we estimate a regression with the abnormal return on the first market day following the buy recommendation (i.e., event window $[1,1]$ ), $\mathrm{AR}_{\mathrm{i} 1}$ as a dependent variable, and the variables corresponding to our conceptual framework as the independent predictors. For all 
TABLE 5

Initial Versus Repeat Buy Recommendations

\begin{tabular}{|c|c|c|c|c|c|c|}
\hline Days & $\mathbf{N}$ & Mean CAR & $\begin{array}{l}\text { Positive: } \\
\text { Negative }\end{array}$ & $\begin{array}{l}\text { Portfolio Time- } \\
\text { Series (CDA) t }\end{array}$ & $\begin{array}{c}\text { Cross-Sectional } \\
\mathbf{t}\end{array}$ & $\begin{array}{c}\text { Generalized } \\
\text { Sign z }\end{array}$ \\
\hline \multicolumn{7}{|c|}{ Initial Recommendations } \\
\hline $\begin{array}{l}(-10,0) \\
(+1,+1) \\
(+2,+20)\end{array}$ & $\begin{array}{l}1069 \\
1069 \\
1069\end{array}$ & $\begin{array}{r}2.02 \% \\
1.42 \% \\
-1.51 \%\end{array}$ & $\begin{array}{l}633: 436^{\star} \\
683: 386^{\star} \\
460: 609^{\star}\end{array}$ & $\begin{array}{r}9.209^{\star} \\
21.471^{\star} \\
-5.215^{\star}\end{array}$ & $\begin{array}{r}4.868^{\star} \\
12.293^{\star} \\
-4.658^{\star}\end{array}$ & $\begin{array}{r}7.340^{*} \\
10.401^{\star} \\
-3.251^{*}\end{array}$ \\
\hline \multicolumn{7}{|c|}{ Repeat Recommendations } \\
\hline $\begin{array}{l}(-10,0) \\
(+1,+1) \\
(+2,+20)\end{array}$ & $\begin{array}{l}7091 \\
7091 \\
7090\end{array}$ & $\begin{array}{r}.80 \% \\
.36 \% \\
-1.49 \%\end{array}$ & $\begin{array}{l}\text { 3761:3330* } \\
\text { 3742:3349* } \\
\text { 3091:3999* }\end{array}$ & $\begin{array}{r}9.874^{\star} \\
14.744^{\star} \\
-14.041^{*}\end{array}$ & $\begin{array}{r}7.897^{\star} \\
12.171^{*} \\
-12.926^{*}\end{array}$ & $\begin{array}{r}8.947^{\star} \\
8.495^{\star} \\
-6.971^{\star}\end{array}$ \\
\hline
\end{tabular}

${ }^{*} p<.001$.

Notes: CAR = cumulative abnormal return. $C D A=$ crude dependence adjustment.

initial buy recommendations, we specify the following model:

$$
\begin{aligned}
& \text { (7) } \mathrm{AR}_{\mathrm{i} 1}=\beta_{\mathrm{pr}} \text { PRIMACY }_{\mathrm{i} 0}+\beta_{\mathrm{rec}} \text { RECENCY }_{\mathrm{i} 0} \\
& +\beta_{\text {Clutter }} \text { CLUTTER_OVERALL }{ }_{\mathrm{i} 0} \\
& +\beta_{\text {SIC_Clutter }} \text { CLUTTER_SIC }{ }_{\mathrm{i} 0} \\
& +\beta_{\mathrm{SM}} \text { SPECIAL_MENTION }_{\mathrm{i} 0}+\beta_{\mathrm{MB}} \mathrm{MON}_{-} \mathrm{BACK}_{\mathrm{i} 0}
\end{aligned}
$$

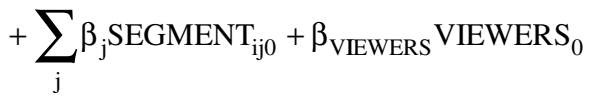

$$
\begin{aligned}
& +\beta_{\text {TIME }} \text { EVENT_DATE }_{\mathrm{i} 0} \\
& +\beta_{\text {price }} \text { SHARE_PRICE }_{\mathrm{i}(-1)}+\beta_{\text {Turn }} \text { TURNOVER }_{\mathrm{i}(-1)} \\
& +\beta_{\mathrm{Cap}} \mathrm{LN}\left(\mathrm{MARKET} \_\mathrm{CAP}_{\mathrm{i}(\mathrm{t}-1)}\right) \\
& +\beta_{\text {NYSE }} \text { NYSE }_{i 1}+\beta_{\text {AMEX }} \text { AMEX }_{i 1} \\
& +\beta_{\text {own }} \text { CRAMER_OWNS }{ }_{\mathrm{i} 0} \\
& +\beta_{\mathrm{MD}} \text { MEMORY_DECAY }{ }_{\mathrm{i} 1}+\eta_{\mathrm{it}} \text {. }
\end{aligned}
$$

For all repeat buy recommendations separately, we estimate the following model:

(8)

$$
\begin{aligned}
& \mathrm{AR}_{\mathrm{i} 1}=\beta_{\mathrm{pr}} \text { PRIMACY }_{\mathrm{i} 0}+\beta_{\text {rec }} \text { RECENCY }_{\mathrm{i} 0} \\
& +\beta_{\text {Clutter }} \text { CLUTTER_OVERALL }{ }_{\mathrm{i} 0} \\
& +\beta_{\text {SIC_Clutter }} \text { CLUTTER_SIC } \\
& +\beta_{\mathrm{SM}_{\mathrm{S}}} \text { SPECIAL_MENTION }_{\mathrm{i} 0}+\beta_{\mathrm{MB}} \mathrm{MON}_{-} \mathrm{BACK}_{\mathrm{i} 0} \\
& +\sum_{\mathrm{j}} \beta_{\mathrm{j}} \text { SEGMENT }_{\mathrm{ij} 0}+\beta_{\text {VIEWERS }} \text { VIEWERS }_{0} \\
& +\beta_{\text {TIME }} \text { EVENT_DATE }_{\mathrm{i} 0} \\
& +\beta_{\mathrm{CA}} \text { RETURN_SINCE_LAST }{ }_{\mathrm{i} 0} \\
& +\beta_{\text {rev }} \text { RECOMMENDATION_REVERSAL }{ }_{\mathrm{i} 0} \\
& +\beta_{\text {int }} \text { RECOMMENDATION_REVERSAL } L_{\mathrm{i} 0} \\
& \times \text { RETURN_SINCE_LAST } 10 \\
& +\beta_{\text {price }} \text { SHARE_PRICE }_{(\mathrm{t}-1)}
\end{aligned}
$$

$$
\begin{aligned}
& +\beta_{\text {Turn }} \text { TURNOVER }_{\mathrm{i}(\mathrm{t}-1)} \\
& +\beta_{\text {Cap }} \text { LN(MARKET_CAP }(\mathrm{i}-1)+\beta_{\text {NYSE }} \text { NYSE }_{\mathrm{i} 1} \\
& +\beta_{\text {AMEX }} \text { AMEX }_{\text {i1 }}+\beta_{\text {own }} \text { CRAMER_OWNS }{ }_{\mathrm{i} 0} \\
& +\beta_{\mathrm{MD}} \text { MEMORY_DECAY } 11 \\
& +\beta_{\mathrm{CI}} \text { COVERAGE_INTENSITY }{ }_{\mathrm{i} 0}+\eta_{\mathrm{it}} \text {. }
\end{aligned}
$$

Independent variables include factors related to information processing (e.g., recency and primacy dummy variables, variables representing overall and Standard Industrial Classification-specific [SIC-specific] clutter), the show's reach, and whether the recommendation had a Special Mention designation. In addition, we capture the date of recommendation, the exchange on which the security was traded at the time of recommendation, share price, turnover, and the market cap characteristics associated with a particular security. For repeat recommendations, we also include variables that represent the accuracy of the host's previous predictions. Appendix A presents the summary of all the variables used in this study. A correlation table for Model 6 (7) is in Appendix B (C). Descriptive statistics are in Appendix D.

\section{Results of Regression Analysis}

Tables 6 and 7 summarize the regression results for Models 6 and 7. In addition to the specified model, we estimated models that omitted the Special Mention designation as an explanatory variable. We do not present the results of these models here (because these models are inferior to the models we summarize based on the incremental F-test $[p<$ $.001]$ ), but it is worth noting that they support the presence of strong between-segment differences that disappear when the Special Mention variable is introduced.

\section{Information-Processing Effects}

$\mathrm{H}_{2}$ and $\mathrm{H}_{3}$, which deal with primacy and recency effects, are both supported. We find convincing evidence for the existence of primacy effects because they are significant $(p<.001)$ for both initial and repeat recommendations. We also find evidence of a significant $(p<.05)$ recency effect in the repeat-recommendations sample. Similar to Pieters and 
Bijmolt (1997), we find that primacy effects are stronger than recency effects.

Clutter. There is some support for $\mathrm{H}_{4}$ because overall information clutter marginally contributes to reducing the size of the market inefficiency following repeat buy recommendations $(p<.10)$. However, overall clutter is not significant for initial recommendations. In addition, contrary to $\mathrm{H}_{5}$, clutter from similar (same SIC header code) picks is positively associated with the size of the inefficiency $(p<$ $.02)$. Although this finding is surprising from an information-processing point of view, it could be explained by the host's tendency to talk about potentially attractive segments and to bring up several stocks he finds particularly promising. These positive remarks about the industry may create elaboration rather than clutter.

Message length. There is strong support for $\mathrm{H}_{6}$, regarding the relationship between message length and the size of the abnormal return. In both regressions, when a recommendation is given a Special Mention designation, the resulting abnormal return is significantly higher $(p<.001)$. In the initial-buy regression, none of the segment variables are significant, indicating that only message length, and not the segment of the show in which it appears or the source of the pick (i.e., user- or host-generated), has an impact. In contrast, in the repeat-buy regressions, there is a positive coefficient for the Lightning Round and Sudden Death seg- ments (which investors tend to favor) and a negative coefficient for the Closing segment. ${ }^{7}$ Therefore, after controlling for the amount of attention given to each stock, we pick up signs of viewer preference for different segment formats. In summary, the strong impact of being a Special Mention stock supports $\mathrm{H}_{6}$, that more elaborate recommendations are associated with larger market inefficiencies.

\section{Reach}

We also find some evidence on the size of audience effects. The Number of Viewers variable is marginally significant in the repeat-recommendation model. ${ }^{8}$ This provides marginal support for $\mathrm{H}_{7}$.

\section{Source Credibility and Learning Effects}

There is mixed evidence for $\mathrm{H}_{8}$, that global learning is taking place. We find that the time variable is significant $(p<$

7This is not surprising, given that Sudden Death is a new segment that was designed to stop the viewers from changing the channel before the end of the program.

${ }^{8}$ A possible explanation for only a marginal effect could be that Mad Money has a group of hardcore followers who are responsible for the bulk of the price movements. The size of the occasional viewer segment (that fluctuates in response to other programming available) may not have a very strong effect on stock prices. This matter requires further investigation.

TABLE 6

Regression Results for Initial Buy Recommendations

\begin{tabular}{|c|c|c|c|c|c|c|c|c|}
\hline \multirow[b]{2}{*}{ Variable } & \multirow[b]{2}{*}{ Hypothesis } & \multicolumn{2}{|c|}{$\begin{array}{l}\text { Unstandardized } \\
\text { Coefficient }\end{array}$} & \multirow{2}{*}{$\frac{\begin{array}{c}\text { Standardized } \\
\text { Coefficient }\end{array}}{\text { Beta }}$} & \multirow[b]{2}{*}{ t-Value } & \multirow[b]{2}{*}{ Significance } & \multicolumn{2}{|c|}{$\begin{array}{l}\text { Collinearity } \\
\text { Statistics }\end{array}$} \\
\hline & & B & SE & & & & Tolerance & VIF \\
\hline $\begin{array}{l}\text { Constant } \\
\text { Primacy } \\
\text { Recency } \\
\text { Overall Clutter } \\
\text { SIC Clutter } \\
\text { Special Mention } \\
\text { 'Mon Back } \\
\text { CEO Segment } \\
\text { Lightning Round } \\
\text { Sudden Death } \\
\text { Closing Segment } \\
\text { Opening Segment } \\
\text { Viewers } \\
\text { Time } \\
\text { Preevent Price } \\
\text { Preevent Turnover } \\
\text { Log(Market Cap) } \\
\text { NYSE } \\
\text { AMEX } \\
\text { Cramer Owns } \\
\text { Memory Decay }\end{array}$ & $\begin{array}{l}\mathrm{H}_{2} \\
\mathrm{H}_{3} \\
\mathrm{H}_{4} \\
\mathrm{H}_{5} \\
\mathrm{H}_{6} \\
\mathrm{H}_{6} \\
\mathrm{H}_{6} \\
\mathrm{H}_{6} \\
\mathrm{H}_{6} \\
\mathrm{H}_{6} \\
\mathrm{H}_{6} \\
\mathrm{H}_{7} \\
\mathrm{H}_{8} \\
\text { Control } \\
\text { Control } \\
\text { Control } \\
\text { Control } \\
\text { Control } \\
\text { Control } \\
\text { Control }\end{array}$ & $\begin{array}{r}3.345 \\
.014 \\
.003 \\
.000 \\
.001 \\
.023 \\
-.001 \\
-.014 \\
.002 \\
-.006 \\
-.005 \\
.004 \\
.010 \\
-.000 \\
-.000 \\
.088 \\
-.004 \\
-.004 \\
.007 \\
.008 \\
-.001\end{array}$ & $\begin{array}{l}1.211 \\
.003 \\
.004 \\
.000 \\
.000 \\
.005 \\
.009 \\
.010 \\
.005 \\
.009 \\
.007 \\
.005 \\
.035 \\
.000 \\
.000 \\
.034 \\
.001 \\
.002 \\
.008 \\
.008 \\
.001\end{array}$ & $\begin{array}{r}.123 \\
.024 \\
-.022 \\
.066 \\
.290 \\
-.003 \\
-.039 \\
.032 \\
-.020 \\
-.022 \\
.025 \\
.008 \\
-.102 \\
-.113 \\
.071 \\
-.159 \\
-.056 \\
.025 \\
.028 \\
-.015\end{array}$ & $\begin{array}{r}2.762 \\
4.246 \\
.814 \\
-.748 \\
2.363 \\
4.514 \\
-.105 \\
-1.413 \\
.518 \\
-.636 \\
-.740 \\
.720 \\
.270 \\
-2.718 \\
-3.646 \\
2.619 \\
-4.461 \\
-1.802 \\
.887 \\
1.003 \\
-.534\end{array}$ & $\begin{array}{l}.006 \\
.000 \\
.416 \\
.455 \\
.018 \\
.000 \\
.916 \\
.158 \\
.605 \\
.525 \\
.459 \\
.472 \\
.787 \\
.007 \\
.000 \\
.009 \\
.000 \\
.072 \\
.375 \\
.316 \\
.594\end{array}$ & $\begin{array}{l}.876 \\
.828 \\
.845 \\
.932 \\
.177 \\
.910 \\
.951 \\
.187 \\
.756 \\
.799 \\
.622 \\
.793 \\
.523 \\
.764 \\
.989 \\
.576 \\
.748 \\
.948 \\
.952 \\
.922\end{array}$ & $\begin{array}{l}1.141 \\
1.208 \\
1.183 \\
1.074 \\
5.640 \\
1.099 \\
1.052 \\
5.341 \\
1.322 \\
1.252 \\
1.608 \\
1.261 \\
1.913 \\
1.309 \\
1.011 \\
1.737 \\
1.337 \\
1.055 \\
1.050 \\
1.084\end{array}$ \\
\hline $\begin{array}{l}\text { Model Fit } \\
\text { R}^{2} \\
\text { Adjusted R² } \\
\text { F-value } \\
\text { Sig. (F) }\end{array}$ & & & & & $\begin{array}{r}.233 \\
.219 \\
15.938 \\
.000\end{array}$ & & & \\
\hline
\end{tabular}

Notes: VIF = variance inflation factor. 
TABLE 7

Regression Results for Repeat Buy Recommendations

\begin{tabular}{|c|c|c|c|c|c|c|c|c|}
\hline \multirow[b]{2}{*}{ Variable } & \multirow[b]{2}{*}{ Hypothesis } & \multicolumn{2}{|c|}{$\begin{array}{c}\text { Unstandardized } \\
\text { Coefficient }\end{array}$} & \multirow{2}{*}{$\begin{array}{c}\begin{array}{c}\text { Standardized } \\
\text { Coefficient }\end{array} \\
\text { Beta }\end{array}$} & \multirow[b]{2}{*}{ t-Value } & \multirow[b]{2}{*}{ Significance } & \multicolumn{2}{|c|}{$\begin{array}{l}\text { Collinearity } \\
\text { Statistics }\end{array}$} \\
\hline & & B & $\overline{S E}$ & & & & Tolerance & VIF \\
\hline Constant & & .053 & .316 & & .169 & .865 & & \\
\hline Primacy & $\mathrm{H}_{2}$ & .004 & .001 & .045 & 3.799 & .000 & .928 & 1.077 \\
\hline Recency & $\mathrm{H}_{3}$ & .002 & .001 & .027 & 2.232 & .026 & .877 & 1.140 \\
\hline Overall Clutter & $\mathrm{H}_{4}$ & -.000 & .000 & -.020 & -1.701 & .089 & .919 & 1.089 \\
\hline SIC Clutter & $\mathrm{H}_{5}^{4}$ & .000 & .000 & .019 & 1.526 & .127 & .881 & 1.136 \\
\hline Special Mention & $\mathrm{H}_{6}$ & .012 & .001 & .220 & 8.274 & .000 & .188 & 5.321 \\
\hline ‘Mon Back & $\mathrm{H}_{6}$ & .003 & .002 & .022 & 1.856 & .064 & .983 & 1.017 \\
\hline CEO Segment & $\mathrm{H}_{6}$ & .000 & .002 & .000 & .023 & .982 & .880 & 1.136 \\
\hline Lightning Round & $\mathrm{H}_{6}^{\circ}$ & .004 & .001 & .085 & 3.627 & .000 & .242 & 4.130 \\
\hline Sudden Death & $\mathrm{H}_{6}$ & .004 & .002 & .029 & 2.142 & .032 & .707 & 1.415 \\
\hline Closing Segment & $\mathrm{H}_{6}$ & -.004 & .001 & -.053 & -3.245 & .001 & .501 & 1.994 \\
\hline Opening Segment & $\mathrm{H}_{6}$ & .002 & .001 & .019 & 1.188 & .235 & .523 & 1.914 \\
\hline Viewers & $\mathrm{H}_{7}^{\circ}$ & .017 & .010 & .024 & 1.765 & .078 & .736 & 1.359 \\
\hline Time & $\mathrm{H}_{8}$ & -.000 & .000 & -.001 & -.092 & .927 & .573 & 1.746 \\
\hline Return Since Last & $\mathrm{H}_{9}^{\circ}$ & .079 & .025 & .040 & 3.133 & .002 & .811 & 1.233 \\
\hline Recommendation & & & & & & & & \\
\hline Reversal & $\mathrm{H}_{10}$ & .003 & .001 & .044 & 3.706 & .000 & .955 & 1.048 \\
\hline Return Since & & & & & & & & \\
\hline $\begin{array}{l}\text { Last } \times \\
\text { Recommendation }\end{array}$ & & & & & & & & \\
\hline Reversal & $\mathrm{H}_{11}$ & .282 & .067 & .053 & 4.209 & .000 & .843 & 1.186 \\
\hline Preevent Price & Control & -.000 & .000 & -.019 & -1.526 & .127 & .861 & 1.162 \\
\hline Preevent Turnover & Control & .028 & .011 & .030 & 2.553 & .011 & .966 & 1.035 \\
\hline Log(Market Cap) & Control & -.002 & .000 & -.123 & -9.055 & .000 & .721 & 1.387 \\
\hline NYSE & Control & -.001 & .001 & -.025 & -1.912 & .056 & .805 & 1.242 \\
\hline AMEX & Control & .002 & .002 & .011 & .923 & .356 & .936 & 1.068 \\
\hline Cramer Owns & Control & .001 & .001 & .009 & .739 & .460 & .933 & 1.072 \\
\hline Coverage Intensity & Control & -.002 & .004 & -.007 & -.575 & .565 & .968 & 1.033 \\
\hline Memory Decay & Control & .000 & .000 & .014 & 1.170 & .242 & .926 & 1.079 \\
\hline \multicolumn{9}{|l|}{ Model Fit } \\
\hline & & & & & .064 & & & \\
\hline Adjusted R2 & & & & & .060 & & & \\
\hline F-value & & & & & 19.98 & & & \\
\hline Sig. (F) & & & & & .0000 & & & \\
\hline
\end{tabular}

Notes: VIF = variance inflation factor.

.01) and negative in the initial-recommendation model. This suggests that the reaction to Cramer's initial buy recommendations decreases over time, which is consistent with the idea that viewers learn that there is some wealth redistribution. However, we do not find a significant effect for time in the repeat-recommendation model. Over time, there is an increase in the number of stocks recommended by Cramer in a single show, and individual stocks receive less attention. Therefore, there is some collinearity between the Special Mention, time, and individual segment variables, but none of the variance inflation factors exceed 10 (the cutoff point that Marguardt [1970] suggests for identifying serious collinearity problems).

In contrast, there is strong evidence in support of $\mathrm{H}_{9}$, $\mathrm{H}_{10}$, and $\mathrm{H}_{11}$, which deal with repeat recommendations on individual stocks. For $\mathrm{H}_{9}$, if Cramer's track record for a particular security is strong (i.e., larger positive returns on recommended buys or steeper stock price declines for recommended sells), investors are significantly more likely to pay attention to his subsequent recommendations for that stock. This is evident in the significant Return Since Last Recommendation variable in the repeat-buy recommendation regressions. Consistent with $\mathrm{H}_{10}$, recommendation reversals are associated with larger abnormal returns, indicating that viewers respond to such reversals strongly. Furthermore, in support of $\mathrm{H}_{11}$, investor return from the last recommendation for a particular equity and its interaction with recommendation reversal are both significant. These results indicate that investors pay attention to Cramer's track record on individual stocks because the response to his recommendation is contingent on the accuracy of his previous prediction for the same security.

\section{Other Significant Findings}

The size of the share price (i.e., preevent share price) is negatively associated with abnormal returns, indicating that investors are "bargain hunting" while watching the show. This finding persists even after we control for other 
variables, such as market cap. Similar to previous research, we find that market cap is inversely related to the size of the abnormal return. In addition, we find that different markets are associated with different sizes of inefficiencies. Stocks traded on the NYSE have marginally lower inefficiencies than NASDAQ stocks. These differences could potentially be linked to differences in the security types listed on these exchanges, levels of idiosyncratic volatility associated with these stocks, differences in effective spread sizes, and shortsales rules governing different exchanges. However, identifying the sources of this variation is beyond the scope of this project.

\section{Managerial Implications}

\section{Summary}

We document several inefficiencies/arbitrage opportunities that are created by televised stock recommendations. These inefficiencies are of interest to the managers of publicly traded companies affected by Mad Money recommendations because they may influence stock repurchase decisions.

We assumed that the response to Jim Cramer's recommendations might differ from the response to advertisements because many viewers are actively looking for recommendations rather than passively watching commercials. We find considerable evidence that viewers are actively looking for recommendations. First, rather than a threshold or inverted U-shaped response curve to the number of advertisements, initial recommendations generated stronger reactions than subsequent recommendations for the same stock. Second, this seems to be a high-involvement purchase. For initial recommendations, it appears that rather than focusing on better-known stocks with large capitalizations, investors are looking for niche/small cap stocks because the size of the next-day stock price abnormality is inversely related to the size of the preevent market capitalization. However, this larger inefficiency could also be explained by the higher limits to arbitrage associated with small cap stocks. In addition, stocks with higher turnover rates generated higher next-day price increases than stocks with lower-turnover/higher-institutional ownership. Finally, lower-priced stocks had greater abnormal returns following initial recommendations, indicating that naive investors could be bargain hunting. This finding underscores the irrationality of naive investor actions and suggests that pricingrelated considerations could inform finance models of investor behavior.

Despite these differences between response to traditional advertising and to Cramer's recommendations, we find numerous similarities. Although a substantial fraction of the audience is looking for recommendations, any individual recommendation is still subject to many of the same communication obstacles as advertisements in terms of getting heard. We found strong evidence of both recency and primacy effects in investor response to stock recommendations. Primacy had a greater impact than recency (and affected both initial and repeat recommendations, while only repeat recommendations were affected by the recency effect), possibly indicating that search is active and that when a satisfactory recommendation is found, the search ends. We found that overall clutter had a marginally negative impact on the reaction to repeat recommendations but had no effect for initial recommendations. This indicates that initial recommendations can cut through the clutter. Contrary to expectations, industry clutter actually increased viewer response. We assume that this was due to the increased visibility of all recommendations in that industry. In addition, recommendations that were given greater emphasis had a greater response than others.

We find that source credibility has a significant impact on the response to subsequent recommendations. There is evidence of global learning because the decrease in response to Cramer's recommendations over time is consistent with viewers learning the general pattern of abnormal returns shown in Figure 3. However, we also find that investors track the host's performance for particular securities when making purchase decisions because response to a particular stock is significantly affected by the success of past recommendations for the same stock, especially if there was a reversal of the previous recommendation.

\section{Implications}

When investors are looking for recommendations, but not a specific stock recommendation, the situation could be similar to when a person has an interest in a product or service class but does not have a specific brand in mind. This similarity should make the findings of this study relevant to the emergent class of well-targeted advertisements (i.e., advertisements that are served to consumers who have expressed some interest in a particular product category). Our findings suggest that it is not enough to appropriately target a message to a certain viewer; its chances of being attended to and acted on are significantly greater with proper placement, reduced clutter, and better execution. For example, in targeted online advertising campaigns, marketers need to make sure not only that the message is going to the right people but also that it is appropriately positioned among the competitive entries and designed in a way that grabs consumer attention and cuts through the clutter.

The findings are also relevant to the domain of searchengine marketing (e.g., Google's AdWords), browsinghistory-based behavioral targeting (e.g., Front Porch, NebuAd, Phorm), and the effectiveness of recommendation lists and advice columns (e.g., the Amazon Daily blog) that are becoming integral parts of Internet shopping portals. Even in such high-involvement environments in which consumers are presented with information relevant to their needs, information-processing-related effects influence their purchasing decisions. According to Microsoft research (i.e., Richardson, Dominowska, and Ragno 2007), higherpositioned advertisements receive higher clickthrough rates as a result of visual attention differences. Our research shows that additional information-processing effects could also have a bearing on the relative effectiveness of search and other types of Internet advertising; namely, there seems to be a connection with banner advertising such that the presentation order must be considered when trying to determine the effectiveness of an advertisement. 
Of interest to search marketers and online advertisers is the notion that in competitive, high-involvement environments in which people are trying to find a unique product, repeated exposure may not produce the desired results. Broader settings that can benefit from this insight are Internet art, designer clothing, and unique jewelry auctions. For example, Portero.com is an auction site dedicated to selling certified "preowned" luxury designer items. The site publishes a blog listing several items designated as great finds. According to our findings, such blogs should be updated frequently and with items not mentioned elsewhere on the Web site. Bidz.com is a site that sells closeout and discontinued jewelry with live auctions starting every five seconds. In such high-involvement, high-paced settings, recommendations should be made out of the pool of items not yet considered by the bidders.

It is instructive to compare the results of this study with those of Tellis and Johnson (2007). In their event analysis of abnormal returns to stock prices of firms whose products were reviewed by the Wall Street Journal, a positive product review by Walter Mossberg provided a larger abnormal next-day return that was sustained in the following days. This suggests that if CEOs introduce credible, positive, new information, its impact on stock returns could be similar to that of an objective product review. If an appearance does not provide any new information (similar to most appearances on Mad Money), its effects dissipate quickly.

It might be better to restrict public relations activities to general business shows and communication with analysts and not to shows such as Mad Money, for which viewers are looking for stock picks. To create a sustainable stock price increase, the appearances should concentrate on the new developments that are material (i.e., affect a company's long-term potential and future cash flows) because the market does not reward the public relations efforts that are not based on fundamentals. At the same time, there could be some positive side effects associated with Mad Money appearances because increased scrutiny may reduce the cost of management/market information asymmetry, which, in efficient markets, is ultimately borne by the firm (Myers and Majluf 1984). In addition, these appearances might create additional brand equity, especially when it comes to relatively unknown consumer goods (viewers could be inclined to try the brands marketed by the companies mentioned on the show), but this aspect needs further investigation.

This study also has implications for marketers and policy makers in the area of complex product offerings in which consumers have limited ability to comprehend prod- ucts' value or efficacy (e.g., investments, health care, education). Our findings suggest that despite the highinvolvement environment associated with these settings, consumers rely on heuristics in making their decisions because they have limited ability to perform their own due diligence. As a result, they blindly follow the "experts" and are especially susceptible to various information-processing biases.

From a public policy perspective, this study finds that naive investors pick investment opportunities without doing much due diligence because they respond to Mad Money stock recommendations as soon as the markets open on the day following the broadcast. Furthermore, their investment decisions are influenced by various information-processing considerations that are not tied to company fundamentals, making them extremely vulnerable to manipulation. By separating the contaminated events from the clean events and providing evidence of price run-up only before the contaminated events, we question the findings of prior studies that attribute the price run-up effect to information leakage. To resolve the issue of information leakage, we advocate further inquiry into the price run-up in the contaminated sample to disentangle the effects of contaminating events from information leakage, if any.

\section{Limitations and Further Research}

This study evaluates a single financial recommendation show. This limitation is brought about because Mad Money is the only program clearly targeted at a naive audience for which we could obtain a suitable data set. Our preliminary research shows that in more sophisticated types of programming, inefficiencies are much smaller and driven primarily by market infrastructure considerations and limits to arbitrage (e.g., turnover, market cap, the exchange on which the security is traded), though some factors related to recommendation credibility and intensity (e.g., analyst consensus, number of panelists supporting a recommendation) are also relevant. Further research should examine the continuum of available programming and provide a framework for identifying the most relevant factors that lead to the size of abnormal returns in different types of financial programming.

This study shows that financial managers and scholars need to draw on the knowledge generated within the marketing field when predicting individual investor reactions to messages pertaining to financial securities. Marketing literature documents a vast array of consumer behavior patterns that can significantly improve the traditional models of investor behavior that rely on investor rationality. 
APPENDIX A

Variables

\begin{tabular}{lcc}
\hline Variable & Hypothesis & Description \\
\hline Abnormal Return & $\begin{array}{c}\text { Dependent } \\
\text { variable } \\
\mathrm{H}_{1}\end{array}$ & $\mathrm{AR}_{\mathrm{i} 1}$ or next-trading-day abnormal return for stock $\mathrm{i}$. \\
Initial & Dummy variable taking on a value of 1.
\end{tabular}

\begin{tabular}{|c|c|c|}
\hline Primacy $_{i j 0}$ & $\mathrm{H}_{2}$ & $\begin{array}{l}\text { Dummy variable taking on a value of } 1 \text { if stock } i \text { was the } \\
\text { first stock recommended in its segment } j .\end{array}$ \\
\hline Recency $_{\mathrm{ij0}}$ & $\mathrm{H}_{3}$ & $\begin{array}{l}\text { Dummy variable taking on a value of } 1 \text { if stock } i \text { was the } \\
\text { last stock recommended in its segment } j \text {. }\end{array}$ \\
\hline Overall Clutter $_{0}$ & $\mathrm{H}_{4}$ & $\begin{array}{l}\text { The number of all positive and negative } \\
\text { recommendations made on the same event show. }\end{array}$ \\
\hline SIC Clutter $_{\text {ido }}$ & $\mathrm{H}_{5}$ & $\begin{array}{l}\text { The number of competing recommendations for stock } i \\
\text { with the same SIC code d made on the same event } \\
\text { show. }\end{array}$ \\
\hline Segment $_{\mathrm{ij} 0}$ & $\mathrm{H}_{6}$ & $\begin{array}{c}\text { Dummy variable array with values taking on a value of } 1 \\
\text { if recommendation for stock i aired during segment j on } \\
t=0 \text {. "Discussion" (also referred to as "Main") segment } \\
\text { stocks and stocks with no segment designation serve as } \\
\text { a reference category. }\end{array}$ \\
\hline Special Mention $_{\mathrm{i} 0}$ & $\mathrm{H}_{6}$ & $\begin{array}{l}\text { Dummy variable indicating whether stock i received a } \\
\text { Special Mention designation on the show at } t=0 \text {. }\end{array}$ \\
\hline 'Mon Back & $\mathrm{H}_{6}$ & $\begin{array}{c}\text { Dummy variable indicating whether stock i received this } \\
\text { designation on the show at } t=0 \text {. }\end{array}$ \\
\hline Viewers $_{0}$ & $\mathrm{H}_{7}$ & $\begin{array}{c}\text { Correspond to Nielsen estimates for the audience size } \\
\text { for the event date, } t=0 .\end{array}$ \\
\hline Time $_{\mathrm{i} 0}$ & $\mathrm{H}_{8}$ & $\begin{array}{c}\text { Date on which recommendation took place; attempts to } \\
\text { capture the investor learning. }\end{array}$ \\
\hline $\begin{array}{l}\text { Return Since } \\
\text { Last }_{(\mathrm{t}-1)}\end{array}$ & $\mathrm{H}_{\mathrm{c}}$ & $\begin{array}{l}\text { Preevent daily return if the last recommendation was } \\
\text { followed; sell stocks are considered sold short. }\end{array}$ \\
\hline $\begin{array}{l}\text { Recommendation } \\
\text { Reversal }_{\mathrm{i} 0}\end{array}$ & $\mathrm{H}_{10}$ & $\begin{array}{l}\text { Dummy variable taking on a value of } 1 \text { if Cramer } \\
\text { changed his recommendation for stock } i \text { at } t=0 \text {. }\end{array}$ \\
\hline
\end{tabular}

$\begin{array}{ll}\begin{array}{ll}\text { Share Price } \\ \text { Turnover }_{i(t-1)}\end{array} & \begin{array}{c}\text { Control } \\ \text { Control }\end{array} \\ \text { Market Capi }_{i(t-1)} & \text { Control } \\ \text { NYSE }_{i 1}, \text { AMEX }_{i 1}, & \text { Control } \\ \text { NADAQ }_{i 1} & \text { Control } \\ \text { Cramer Owns } & \\ \begin{array}{c}\text { Coverage } \\ \text { Intensity }\end{array} & \text { Control } \\ \text { Memory Decay } & \text { Control }\end{array}$

Per share price for company i before the event Turnover ratio of stock i before the recommendation.

Market cap of company i before the recommendation.

Market on which a given security $\mathrm{i}$ is traded.

Cramer's charitable trust owns a particular stock $i$ at the time of recommendation.

Intensity of coverage for stock i before the given event at $\mathrm{t}=0$.

Dummy variable that takes on a value of 1 if Number of Days Since Recommendation for stock i until market
Special Details

Variable is used to sort the database into the initial versus unique recommendation samples.

SIC grouping is based on twodigit SIC code header.

Array columns are CEO Interview, Lightning Round, Opening Segment, Closing Segment, and Sudden Death.

Interaction of this and Return Since Last variables is used to test $\mathrm{H}_{11}$.

Number of shares traded over number of shares outstanding. Log-transformed in regression equations.

NASDAQ serves as a reference category. opens on $\mathrm{t}=1$.

aWe also tried capturing day of the week and holiday break effects. Friday variable in the Weekday array and Memory Decay variables are highly correlated; therefore, we explored using just the decay variable versus using day-of-week variables and the variable called Holiday, which signifies that the next work day after recommendation falls on one of the official exchange holidays. Neither of the methods produced any significant results in terms of influencing the next-day abnormal return. For simplicity of exposition, the final model uses the Memory Decay variable only. 


\section{APPENDIX B}

Correlation Table for Initial Buy Recommendations

\begin{tabular}{|c|c|c|c|c|c|c|c|c|c|c|c|c|c|c|c|c|c|c|c|c|c|}
\hline & 1 & 2 & 3 & 4 & 5 & 6 & 7 & 8 & 9 & 10 & 11 & 12 & 13 & 14 & 15 & 16 & 17 & 18 & 19 & 20 & 21 \\
\hline 1. Abnormal Return & 1.00 & & & & & & & & & & & & & & & & & & & & \\
\hline 2. Primacy & .20 & 1.00 & & & & & & & & & & & & & & & & & & & \\
\hline 3. Recency & .10 & -.06 & 1.00 & & & & & & & & & & & & & & & & & & \\
\hline 4. Overall Clutter & -.03 & -.04 & -.07 & 1.00 & & & & & & & & & & & & & & & & & \\
\hline 5. SIC Clutter & .09 & -.05 & -.04 & .14 & 1.00 & & & & & & & & & & & & & & & & \\
\hline 6. Special Mention & .36 & .24 & .29 & -.07 & .01 & 1.00 & & & & & & & & & & & & & & & \\
\hline 7. 'Mon Back & .04 & .03 & .04 & -.05 & -.03 & .12 & 1.00 & & & & & & & & & & & & & & \\
\hline 8. CEO Segment & -.01 & -.04 & .14 & -.09 & .02 & .11 & -.01 & 1.00 & & & & & & & & & & & & & \\
\hline 9. Lightning Round & -.30 & -.27 & -.31 & .01 & -.04 & -.86 & -.10 & -.10 & 1.00 & & & & & & & & & & & & \\
\hline 10. Sudden Death & -.06 & .09 & .03 & .00 & .02 & -.10 & -.02 & -.01 & -.14 & 1.00 & & & & & & & & & & & \\
\hline 11. Closing Segment & .02 & .11 & -.04 & -.08 & -.08 & .21 & -.02 & .04 & -.18 & -.02 & 1.00 & & & & & & & & & & \\
\hline 12. Opening Segment & .10 & .09 & .22 & -.08 & -.07 & .32 & .27 & -.03 & -.27 & -.03 & -.04 & 1.00 & & & & & & & & & \\
\hline 13. Viewers & .05 & -.04 & -.03 & -.01 & .07 & .01 & -.11 & .00 & .04 & -.09 & -.07 & -.24 & 1.00 & & & & & & & & \\
\hline 14. Time & -.04 & .11 & .11 & -.30 & -.14 & .06 & .13 & .03 & -.10 & .18 & .27 & .42 & -.39 & 1.00 & & & & & & & \\
\hline 15. Share Price $_{(t-1)}$ & -.25 & -.05 & -.05 & .05 & -.03 & -.14 & -.07 & -.04 & .10 & .03 & -.01 & -.07 & -.02 & -.04 & 1.00 & & & & & & \\
\hline 16. Turnover $_{(t-1)}$ & .07 & -.01 & -.01 & .05 & .02 & -.02 & .00 & .00 & .03 & .00 & -.01 & -.01 & -.03 & .03 & -.03 & 1.00 & & & & & \\
\hline 17. Log(Market Cap) & -.32 & -.12 & -.10 & .11 & -.01 & -.29 & -.07 & -.01 & .23 & -.02 & -.04 & -.09 & .03 & -.18 & .47 & -.05 & 1.00 & & & & \\
\hline 18. NYSE & -.22 & -.09 & .01 & .04 & -.12 & -.12 & .01 & .00 & .08 & .03 & -.01 & -.03 & -.03 & -.02 & .27 & -.04 & .45 & 1.00 & & & \\
\hline 19. AMEX & .06 & .01 & -.03 & -.02 & -.01 & .02 & -.02 & -.02 & -.02 & -.02 & .06 & .02 & .00 & .10 & -.08 & .00 & -.12 & -.18 & 1.00 & & \\
\hline 20. Cramer Owns & -.02 & -.05 & .00 & .07 & .01 & -.05 & -.02 & -.01 & .02 & -.02 & -.02 & .00 & .00 & -.09 & .08 & .00 & .16 & .00 & .03 & 1.00 & \\
\hline 21. Memory Decay & -.01 & .00 & .05 & .03 & -.09 & .03 & -.06 & .02 & .04 & -.07 & .05 & .02 & -.13 & -.04 & .06 & -.02 & -.02 & .01 & -.03 & -.02 & 1.00 \\
\hline
\end{tabular}

Notes: Correlations significant at $95 \%$ confidence level are in bold. 
APPENDIX C

Correlation Table for Repeat Buy Recommendations

\begin{tabular}{|c|c|c|c|c|c|c|c|c|c|c|c|c|c|c|c|c|c|c|c|c|c|c|c|c|c|}
\hline Variable & 1 & 2 & 3 & 4 & 5 & 6 & 7 & 8 & 9 & 10 & 11 & 12 & 13 & 14 & 15 & 16 & 17 & 18 & 19 & 20 & 21 & 22 & 23 & 24 & 25 \\
\hline 1. Abnormal Return & 1.00 & & & & & & & & & & & & & & & & & & & & & & & & \\
\hline 2. Primacy & .06 & 1.00 & & & & & & & & & & & & & & & & & & & & & & & \\
\hline 3. Recency & .05 & -.03 & 1.00 & & & & & & & & & & & & & & & & & & & & & & \\
\hline 4. Overall Clutter & -.02 & -.09 & -.07 & 1.00 & & & & & & & & & & & & & & & & & & & & & \\
\hline 5. SIC Clutter & .01 & -.02 & -.04 & .14 & 1.00 & & & & & & & & & & & & & & & & & & & & \\
\hline 6. Special Mention & .14 & .16 & .19 & .04 & -.03 & 1.00 & & & & & & & & & & & & & & & & & & & \\
\hline 7. 'Mon Back & .02 & .04 & .00 & -.04 & -.04 & .02 & 1.00 & & & & & & & & & & & & & & & & & & \\
\hline 8. CEO Segment & .03 & .01 & .23 & -.05 & -.04 & .20 & .01 & 1.00 & & & & & & & & & & & & & & & & & \\
\hline 10. Sudden Death & -.01 & .07 & .09 & .03 & -.01 & -.11 & .01 & -.02 & -.23 & 1.00 & & & & & & & & & & & & & & & \\
\hline 11. Closing Segment & .02 & .08 & .10 & .03 & -.06 & .49 & .00 & .25 & -.39 & -.06 & 1.00 & & & & & & & & & & & & & & \\
\hline 12. Opening Segment & .08 & .09 & .05 & .08 & .01 & .47 & .03 & -.02 & -.37 & -.06 & -.10 & 1.00 & & & & & & & & & & & & & \\
\hline 13. Viewers & .03 & -.03 & -.04 & -.16 & .07 & -.08 & -.03 & -.02 & .14 & -.05 & -.12 & -.12 & 1.00 & & & & & & & & & & & & \\
\hline 14. Time & -.03 & .09 & .10 & .04 & -.10 & .10 & .07 & .05 & -.25 & .10 & .26 & .26 & -.47 & 1.00 & & & & & & & & & & & \\
\hline $\begin{array}{l}\text { 15. Return Since Last } \\
\text { 16. Recommendation }\end{array}$ & .08 & -.01 & -.01 & .07 & .07 & .01 & -.04 & .02 & -.02 & -.02 & .00 & .01 & .02 & -.02 & 1.00 & & & & & & & & & & \\
\hline $\begin{array}{l}\text { Reversal } \\
\text { 17. Return Since } \\
\text { Last } \times \\
\text { Recommendation }\end{array}$ & .07 & .01 & .00 & .01 & .01 & .02 & -.04 & .01 & -.03 & .00 & -.02 & .01 & .00 & .00 & .01 & 1.00 & & & & & & & & & \\
\hline Reversal & .08 & -.02 & -.01 & .02 & .03 & .00 & -.01 & .00 & .00 & .00 & .01 & .00 & .01 & .00 & .36 & .14 & 1.00 & & & & & & & & \\
\hline 18. Share Price $(t-1)$ & -.06 & .00 & .01 & .01 & .00 & .04 & .00 & -.04 & -.05 & -.01 & .03 & .06 & -.02 & .08 & -.05 & -.09 & -.02 & 1.00 & & & & & & & \\
\hline 19. Turnover $_{(t-1)}$ & .05 & .01 & .01 & .00 & .01 & .01 & .00 & .00 & -.01 & -.01 & -.01 & .01 & .03 & .00 & .16 & .01 & .01 & -.01 & 1.00 & & & & & & \\
\hline 20. Log(Market Cap) & -.15 & .00 & -.05 & .03 & .07 & -.01 & .02 & -.08 & -.04 & .01 & .00 & .09 & -.05 & .11 & -.08 & -.09 & -.02 & .35 & -.05 & 1.00 & & & & & \\
\hline 21. NYSE & -.07 & .01 & -.01 & -.02 & -.24 & .02 & -.02 & -.01 & -.05 & .01 & .01 & .03 & -.06 & .08 & -.06 & -.02 & -.03 & .04 & -.01 & .29 & 1.00 & & & & \\
\hline 22. AMEX & .03 & -.01 & .00 & -.01 & .00 & -.03 & .00 & .00 & .04 & .00 & -.02 & -.04 & .03 & -.04 & .01 & .00 & -.02 & -.10 & .00 & -.15 & -.22 & 1.00 & & & \\
\hline 23. Cramer Owns & -.03 & .00 & -.01 & .00 & -.01 & .02 & .02 & -.03 & .00 & -.02 & .01 & .01 & .01 & -.02 & -.04 & -.11 & -.01 & .10 & -.01 & .23 & .06 & -.02 & 1.00 & & \\
\hline 24. Coverage Intensity & .01 & -.02 & .02 & .04 & .03 & .02 & -.01 & .02 & -.02 & -.02 & -.01 & -.02 & .00 & -.08 & .13 & -.02 & .00 & -.02 & .00 & -.05 & -.01 & .02 & -.01 & 1.00 & \\
\hline 25. Memory Decay & .01 & -.03 & -.03 & .09 & -.07 & .11 & -.02 & -.02 & -.05 & -.09 & .16 & .04 & -.17 & .06 & .01 & .00 & .00 & .01 & -.01 & -.01 & .02 & -.02 & .00 & .00 & 1.00 \\
\hline
\end{tabular}




\begin{tabular}{|c|c|c|c|c|c|c|}
\hline \multirow[b]{3}{*}{ Variable } & \multicolumn{3}{|c|}{$\begin{array}{c}\text { APPENDIX D } \\
\text { Descriptive Statistics }\end{array}$} & \multirow{2}{*}{\multicolumn{3}{|c|}{ Repeat Recommendations }} \\
\hline & \multicolumn{3}{|c|}{ Initial Recommendations } & & & \\
\hline & M & SD & $\mathbf{N}$ & M & SD & $\mathbf{N}$ \\
\hline Abnormal Return & .0142 & .038 & 1069 & .0035 & .025 & 7091 \\
\hline Primacy & .12 & .329 & 1069 & .096 & .295 & 7091 \\
\hline Recency & .10 & .303 & 1069 & .109 & .312 & 7091 \\
\hline Overall Clutter & 35.66 & 8.355 & 1069 & 34.382 & 8.675 & 7091 \\
\hline SIC Clutter & 5.00 & 4.087 & 1069 & 5.300 & 4.254 & 7091 \\
\hline Special Mention & .39 & .488 & 1069 & .300 & .458 & 7091 \\
\hline 'Mon Back & .01 & .118 & 1069 & .028 & .166 & 7091 \\
\hline CEO Segment & .01 & .105 & 1069 & .017 & .129 & 7091 \\
\hline Lightning Round & .54 & .499 & 1069 & .597 & .491 & 7091 \\
\hline Sudden Death & .02 & .125 & 1069 & .034 & .182 & 7091 \\
\hline Closing Segment & .03 & .163 & 1069 & .093 & .291 & 7091 \\
\hline Opening Segment & .06 & .239 & 1069 & .090 & .286 & 7091 \\
\hline Viewers & .13 & .033 & 1069 & .125 & .034 & 7091 \\
\hline Time & 04/27/2006 & $18200: 42: 18$ & 1069 & $10 / 06 / 2006$ & 184 07:25:02 & 7091 \\
\hline Return Since Last & & & & .002 & .013 & 7091 \\
\hline Recommendation Reversal & & N.A. & & .135 & .342 & 7091 \\
\hline Return Since Last $\times$ Recommendation Reversal & & & & .000 & .005 & 7091 \\
\hline${\text { Share } \text { Price }_{(t-1)}}$ & 39.26 & 28.733 & 1069 & 53.799 & 56.406 & 7091 \\
\hline Turnover $_{(t-1)}(\mathrm{t}-1)$ & .00 & .031 & 1069 & .001 & .027 & 7091 \\
\hline Log(Market Cap) & 14.70 & 1.550 & 1069 & 16.142 & 1.713 & 7091 \\
\hline NYSE & .61 & .489 & 1069 & .620 & .486 & 7091 \\
\hline AMEX & .02 & .139 & 1069 & .028 & .166 & 7091 \\
\hline Cramer Owns & .02 & .129 & 1069 & .110 & .313 & 7091 \\
\hline Coverage Intensity & & N.A. & & .007 & .082 & 7091 \\
\hline Memory Decay & 1.44 & .859 & 1069 & 1.442 & .855 & 7091 \\
\hline
\end{tabular}

Notes: N.A. = not applicable.

\section{REFERENCES}

Agarwal Jagdish and Wagner A. Kamakura (1995), "The Economic Worth of Celebrity Endorsers: An Event Study Analysis," Journal of Marketing, 59 (July), 56-62.

Alvarez, Michael R. and Jonathan Nagler (2002), "Party System Compactness: Measurement and Consequences," Political Analysis, 12 (1), 46-62.

American Marketing Association (1960), Definitions: A Glossary of Marketing Terms. Chicago: American Marketing Association.

Anand, Punam and Brian Sternthal (1990), "Ease of Message Processing as a Moderator of Repetition Effects in Advertising," Journal of Marketing Research, 27 (August), 345-53.

Balasubramanian, Siva K., Ike Mathur, and Ramendra Thakur (2005), "The Impact of High-Quality Firm Achievements on Shareholder Value: Focus on Malcolm Baldrige and J.D. Power and Associates Awards," Journal of the Academy of Marketing Science, 33 (4), 413-22.

Barber, Brad M., Reuven Lehavy, and Maureen McNichols (2001), "Can Investors Profit From the Prophets? Security Analyst Recommendations and Stock Returns," Journal of Finance, 56 (2), 531-63.

— and Terrance Odean (2008), "All That Glitters: The Effect of Attention and News on the Buying Behavior of Individual and Institutional Investors," The Review of Financial Studies, 21 (2), 785-818.

Barberis, Nicholas and Richard Thaler (2003), "A Survey of Behavioral Finance," in The Handbook of the Economics of Finance, Vol. 1, George M. Constantinides, Milton Harris, and Rene Stulz, eds. Amsterdam: Elsevier, 1053-1128.
Bettman, James R. (1979), An Information Processing Theory of Consumer Choice. Reading, MA: Addison-Wesley.

Blair, Margaret H. (1987), "An Empirical Investigation of Advertising Wearin and Wearout," Journat of Advertising Research, 27 (December-January), 45-50.

Boehmer, Ekkehart, Jim Musumeci, and Annett B. Poulsen (1991), "Event Study Methodology Under Conditions of EventInduced Variance," Journal of Financial Economics, 30 (2), 253-72.

Bollerslev, Tim (1986), "Generalized Autoregressive Conditional Heteroskedasticity," Journal of Econometrics, 31 (3), 307-327.

Brown, Stephen and Michael L. Rothschild (1993), "Reassessing the Impact of Television Advertising Clutter," Journal of Consumer Research, 20 (1), 138-46.

and Jerold Warner (1985), "Using Daily Stock Returns: The Case of Event Studies," Journal of Financial Economics, 14 (1), 3-31.

Burke, Raymond R. and Thomas K. Srull (1988), "Competitive Interference and Consumer Memory for Advertising," Journal of Consumer Research, 15 (1), 55-68.

Busse, Jeffrey and Clifton Green (2002), "Market Efficiency in Real Time," Journal of Financial Economics, 65 (3), 415-37.

Campbell, Cynthia J. and Charles E. Wasley (1996), "Measuring Abnormal Trading Volume for Samples of NYSE/ASE and NASDAQ Securities Using Parametric and Nonparametric Test Statistics," Review of Quantitative Finance and Accounting, 33 (1), 73-92.

Campbell, John Y., Andrew W. Lo, and A. Craig MacKinlay (1997), "Event-Study Analysis," in The Econometrics of Finan- 
cial Markets. Princeton, NJ: Princeton University Press, 149-80.

Carhart, Mark (1997), "On Persistence in Mutual Fund Performance," Journal of Finance, 52 (1), 57-82.

Chan, Louis K., Josef Lakonishok, and Theodore Sougiannis (2001), "The Stock Market Valuation of Research and Development Expenditures," Journal of Finance, 56 (December), 2431-56.

Chaney, Paul K., Timothy M. Devinney, and Russell S. Winer (1991), "The Impact of New Product Introductions on the Market Value of Firms," Journal of Business, 64 (October), 573-610.

Corhay, Albert and Alireza Tourani-Rad (1996), "Conditional Heteroskedasticity Adjusted Market Model and an Event Study," Quarterly Review of Economics and Finance, 36 (4), 529-38.

Cowan, Arnold R. (1992), "Nonparametric Event Study Tests," Review of Quantitative Finance and Accounting, 2 (4), 343-58.

Cramer, James J. (with Cliff Mason) (2006), Jim Cramer's MAD Money: Watch TV, Get Rich. New York: Simon and Schuster.

Dahlén, Micael and Mats Edenius (2007), "When Is Advertising Advertising? Comparing Responses to Non-Traditional and Traditional Advertising Media," Journal of Current Issues \& Research in Advertising, 29 (1), 33-42.

Diamond, Douglas W. and Robert E. Verrecchia (1987), "Constraints on Short-Selling and Asset Price Adjustment to Private Information," Journal of Financial Economics, 18 (June), 277-311.

Eliashberg, Jehoshua and Thomas S. Robertson (1988), "New Product Preannouncing Behavior: A Market Signaling Study," Journal of Marketing Research, 25 (August), 282-92.

Elton, J. Edwin, Martin J. Gruber, and Seth Grossman (1986), "Discrete Expectational Data and Portfolio Performance," Journal of Finance, 41 (3), 699-713.

Engelberg, Joseph, Caroline Sasseville, and Jared Williams (2006), "Is the Market Mad? Evidence from Mad Money," working paper, Kellogg School of Management, Northwestern University.

- - , and (2007), "Attention and Asset Prices: The Case of Mad Money," working paper, Kellogg School of Management, Northwestern University.

Erdem, Tulin and Michael P. Keane (1996), "Decision-Making Under Uncertainty: Capturing Dynamic Brand Choice Processes in Turbulent Consumer Goods Markets," Marketing Science, 15 (1), 1-21.

Fama, Eugene and Kenneth French (1996), "Multifactor Explanations of Asset Pricing Anomalies," Journal of Finance, 51 (December), 55-84.

Folkes, Valerie S. (1984), "Consumer Reactions to Product Failure: An Attributional Approach," Journal of Consumer Research, 10 (4), 398-409.

Frazzini, Andrea and Owen A. Lamont (2008), "Dumb Money: Mutual Fund Flows and the Cross-Section of Stock Returns," Journal of Financial Economics, 88 (2), 299-322.

Frieder, Laura and Jonathan Zittrain (2007), "Spam Works: Evidence from Stock Touts and Corresponding Market Activity," Harvard Public Law Working Paper No. 135.

Gough, Paul (2006), “"Mad' Man Adds Insight to CNBC Money News," Hollywood Reporter, (March 28), (accessed July 4, 2009), [available at http://www.hollywoodreporter.com/hr/ search/article_display.jsp?vnu_content_id=1002237153].

Haley, Russell (1978), "Sales Effects of Media Weight," Journal of Advertising Research, 18 (June), 9-18.

Hovland, Carl I., Irving L. Janis, and Harold H. Kelley (1953), Communication and Persuasion: Psychological Studies of Opinion Change. New Haven, CT: Yale University Press.

Huberman, G. (2001), "Familiarity Breeds Investment," The Review of Financial Studies, 14 (3), 659-80.
Jain, Prem C. and Joanna S. Wu (2000), "Truth in Mutual Fund Advertising: Evidence on Future Performance and Fund Flows," Journal of Finance, 55 (2), 937-58.

Johnson, Joseph, Gerard J. Tellis, and Deborah MacInnis (2005), "Losers, Winners, and Biased Trades," Journal of Consumer Research, 32 (2), 324-29.

Kalaignanam, Kartik, Venkatesh Shankar, and Rajan Varadarajan (2007), "Asymmetric New Product Development Alliances: Win-Win or Win-Lose Partnerships?" Management Science, 53 (3), 357-74

Keller, Kevin L. (1987), "Memory Factors in Advertising: The Effect of Advertising Retrieval Cues on Brand Evaluations," Journal of Consumer Research, 14 (4), 316-33.

(1991), "Memory and Evaluation Effects in Competitive Advertising Environments," Journal of Consumer Research, 17 (1), 463-76.

Kent, Robert J. and Chris T. Allen (1993), "Does Competitive Clutter in Television Advertising 'Interfere' with the Recall and Recognition of Brand Names and Ad Claims?" Marketing Letters, 4 (2), 175-84.

Lim, Bryan and Joao Rosario (2008), "The Performance and Impact of Stock Picks Mentioned on 'Mad Money," (February 18), (accessed July 4, 2009), [available at http://ssrn.com/ abstract $=1017353]$.

Marguardt, Donald (1970), "Generalized Inverses, Ridge Regression, Biased Linear Estimation, and Nonlinear Estimation," Technometrics, 12 (3), 591-612.

Mathur, Ike, Kimberly C. Gleason, Selahattin Dibooglu, and Manohar Singh (2002), "Contagion Effects from the 1994 Mexican Peso Crisis: Evidence from Chilean Stocks," The Financial Review, 37 (1), 17-34.

McGill, Ann (1991), "Predicting Consumers' Reactions to Product Failure: Do Responsibility Judgments Follow from Consumers' Causal Explanations?" Marketing Letters, 2 (1), 59-70.

Myers, Stewart C. and Nicholas S. Majluf (1984), "Corporate Financing and Investment Decisions When Firms Have Information That Investors Do Not Have," Journal of Financial Economics, 13 (2), 187-221.

Neumann, John J. and Peppi M. Kenny (2007), "Does Mad Money Make the Market Go Mad?" The Quarterly Review of Economics and Finance, 47 (5), 602-615.

Olson, Jerry C. and Philip A. Dover (1978), "Cognitive Effects of Deceptive Advertising," Journal of Marketing Research, 15 (February), 29-39.

Pari, Robert A. (1987), "Wall \$treet Week Recommendations: Yes or No?" Journal of Portfolio Management, 14 (1), 74-76.

Pechmann, Cornelia and David W. Stewart (1988), "Advertising Repetition: A Critical Review of Wearin and Wearout," in Current Issues and Research in Advertising, James H. Leigh and Claude R. Martin Jr., eds. Ann Arbor: University of Michigan, 285-330.

Pieters, Rik G.M. and Tammo H.A. Bijmolt (1997), "Consumer Memory for Television Advertising: A Field Study of Duration, Serial Position, and Competition Effects," Journal of Consumer Research, 23 (4), 362-72.

___ Luk Warlop, and Michael Wedel (2002), "Breaking Through the Clutter: Benefits of Advertisement Originality and Familiarity for Brand Attention and Memory," Management Science, 48 (6), 765-81.

Richardson, Matthew, Ewa Dominowska, and Robert Ragno (2007), "Predicting Clicks: Estimating the Click-Through Rate for New Ads," in Proceedings of the 16th International Conference on World Wide Web. New York: Association for Computing Machinery, 521-30.

Senchack, A.J., Jr., and Laura T. Starks (1993), "Short-Sale Restrictions and Market Reaction to Short-Interest Announce- 
ments," Journal of Financial and Quantitative Analysis, 28 (2), 177-94.

Sharma, Anurag and Nelson Lacey (2004), "Linking Product Development Outcomes to Market Valuation of the Firm: The Case of the U.S. Pharmaceutical Industry," Journal of Product Innovation Management, 21 (5), 297-308.

Simon, Carol and Mary W. Sullivan (1993), "The Measurement and Determinants of Brand Equity: A Financial Approach," Marketing Science, 12 (1), 28-52.

Simon, Hermann (1982), "ADPULS: An Advertising Model with Wearout and Pulsation," Journal of Marketing Research, 19 (August), 352-63.

Sood, Ashish and Gerard J. Tellis (2009), "Do Innovations Really Pay Off? Total Stock Market Returns to Innovation," Marketing Science, 28 (3), 442-56.

Sprent, Peter (1989), Applied Nonparametric Statistical Methods. London: Chapman and Hall.

Srinivasan, Raji and Sundar Bharadwaj (2004), "Event Studies in Marketing Strategy Research," in Assessing Marketing Strategy Performance, Christine Moorman and Donald R. Lehmann, eds. Cambridge, MA: Marketing Science Institute, 9-28.

The Stalwart (2005), "Jim Cramer Might Be a Liar," (July 26), (accessed July 6, 2009), [available at http://www.thestalwart. com/the_stalwart/2005/07/jim_cramer_migh.html].

Tavits, Margit (2007), "Principle vs. Pragmatism: Policy Shifts and Political Competition," American Journal of Political Science, 51 (1), 151-65.

Television Bureau of Advertising (2009), "Media Trends Track: TNS Media Intelligence Annual Averages," (accessed July 6,
2009), [available at http://www.tvb.org/rcentral/mediatrends track/tvbasics/26_Net_TV_Activity.asp].

Tellis, Gerard J. and Joseph Johnson (2007), "The Value of Quality," Marketing Science, 26 (6), 758-73.

Webb, Peter H. (1979), "Consumer Initial Processing in a Difficult Media Environment," Journal of Consumer Research, 6 (3), 225-36.

and Michael L. Ray (1979), "Effects of TV Clutter," Journal of Advertising Research, 19 (3), 7-12.

Wheatley, John J. (1968), "Influence of Commercial's Length and Position," Journal of Marketing Research, 5 (May), 199-202.

White, Halbert (1982), "Instrumental Variables Regression with Independent Observations," Econometrica, 50 (2), 483-500.

Wiles, Michael A. and Anna Danielova (2009), "The Worth of Product Placement in Successful Films: An Event Study Analysis," Journal of Marketing, 73 (July), 44-63.

Winter, Fredrick W. (1973), "A Laboratory Experiment of Individual Attitude Response to Advertising Exposure," Journal of Marketing Research, 10 (May), 130-40.

Womack, Kent L. (1996), “Do Brokerage Analysts' Recommendations Have Investment Value?" Journal of Finance, 51 (1), 137-67.

Zellner, Arnold (1962), "An Efficient Method of Estimating Seemingly Unrelated Regressions and Tests for Aggregation Bias," Journal of the American Statistical Association, 57 (298), $348-68$.

Zhao, Xinshu (1997), "Clutter and Serial Order Redefined and Retested," Journal of Advertising Research, 37 (5), 57-73. 
Copyright of Journal of Marketing is the property of American Marketing Association and its content may not be copied or emailed to multiple sites or posted to a listserv without the copyright holder's express written permission. However, users may print, download, or email articles for individual use. 